\title{
Informe cultura e sustentabilidade. A cultura, cuarto piar da sustentabilidade
}

COORDINACIÓN: FRAN QUIROGA COLABORACIÓN: LAURA TOBÍO

DOI: $10.17075 /$ ics.2021 


\section{ÍNDICE}

Limiar

Unha cultura para soster o mundo

Cara a unha xestión comunitaria da cultura: sobre a sustentabilidade $\quad 6$

$\begin{array}{ll}\text { O dereito á cultura como base necesaria para a sustentabilidade } & 7\end{array}$

$\begin{array}{ll}\text { Sustentabilidade ambiental } & 8\end{array}$
económica

Cara a unha economía compatible coa vida: sustentabilidade $\quad 9$

A cultura ante a Axenda $2030 \quad 11$

A cultura como catalizador: a imaxinación ao servizo do cambio 12

Os 14 puntos definitorios da cultura e sustentabilidade 13

$\begin{array}{ll}\text { A sustentabilidade na práctica cultural } & 16\end{array}$

$\begin{array}{ll}\text { A Arca da Noe } & 17\end{array}$

$\begin{array}{lr}\text { Brigadas deseucaliptizadoras } & 19\end{array}$

$\begin{array}{ll}\text { Canle Ribeira Sacra } & 21\end{array}$

$\begin{array}{ll}\text { Festival Agrocuir da Ulloa } & 24\end{array}$

$\begin{array}{ll}\text { Festival de Cans } & 27\end{array}$

Festival de Pardiñas (Asociación Xermolos) 29

Rede Aldear $\quad 32$

Rede Galega de Sementes $\quad 35$

$\begin{array}{ll}\text { Rede do Patrimonio Cultural } & 37\end{array}$

$\begin{array}{ll}\text { Rural Mutante } & 39\end{array}$

Recomendacións para unhas políticas públicas activadoras do cambio 
O peak oil, a sexta extinción, o quecemento global, o despoboamento, o abandono da terra ou a perda de falantes das linguas minorizadas alertan dos perigos da era do antropoceno na que nos situamos. A homoxeneidade, a excesiva dependencia fósil ou a crecente forza dos populismos son consecuencias dun sistema económico e simbólico/subxectivo que non pon a vida no centro. Ante isto cómpre preguntarse como pode sosterse o mundo e cal pode ser o papel que xoga a cultura nunha inevitable transición socioecolóxica.

A visión da cultura como industria esquece unha serie de prácticas e procesos culturais que están contribuíndo a ensanchar o común, a superar visións dicotómicas (natureza versus cultura, por exemplo), a repensar a escala, a proximidade, a ensaiar esas outras formas de estar xuntos recuperando saberes tradicionais ou prototipando alternativas que transforman este presente. Debates como o rewilding, a aposta polo relacional, o cuestionamento da norma ou a superación da idea do dominio da natureza por parte do ser humano son espazos onde tamén opera a cultura, e a cultura fai mundos.

Cómpre atender as propostas culturais que sitúan, dunha maneira ou doutra, a vida no centro, que procuran procesos de transformación social, que vertebran territorio e tecen comunidades. Niso, Galicia é vizosa e boa proba son as múltiples festas populares organizadas polos vigairos das comisións de festas, en moitas ocasións por sorteo, ou o propio baile tradicional, cunha ampla malla de escolas, agrupacións e asociacións que autoorganizan foliadas e representacións ao longo de todo o país. Poñer o foco no mantemento e sustentabilidade destes procesos, nesta realidade tan ampla e vivida, é un exercicio de corresponsabilidade colectiva, do que cadaquén forma parte en función das súas responsabilidades políticas, académicas, activistas ou administrativas.

A vontade deste informe é desvelar aquelas prácticas culturais que poñen o foco no relacional, na proximidade, na terra, no miúdo, na transformación, que coidan as xenealoxías e que desde o seu propio facer constrúen presentes pensando no mañá. O informe Cultura e Sustentabilidade non pretende ser un exercicio abstracto desconectado da realidade, polo que se ofrece nel un diálogo cos propios facedores de proxectos culturais, o que permite compoñer unha cartografía de alcances e tensións da aposta pola cultura como eixo vertebrador da sustentabilidade. Non se trata só de amosar proxectos, senón de extraer 
aprendizaxes que deriven en respostas que empurren por un ecosistema máis resiliente.

As prácticas culturais analizadas, ademais de caracterizarse por situarse no eido da sustentabilidade, son unha excelente oportunidade de aprendizaxe social e institucional, un potencial espazo de transferencia e incidencia no deseño das políticas públicas. A cultura é un laboratorio experimental de encontro e participación e, entre moitas das súas claves, atópase a xeración de axenciamento por parte das comunidades, a posibilidade de réplica e afectación social ou outros modos de facer que tramen desde a horizontalidade e/ou o común. Así, a través das aprendizaxes que emerxen desta radiografía, propóñense cinco principios que artellan dez recomendacións no deseño de políticas públicas que alenten e promovan unha cultura para a sustentabilidade.

Como conclusión do informe, preséntase un mecanismo de autoavaliación do grao de sustentabilidade na práctica cultural. A través das respostas a unha serie de preguntas, calquera persoa interesada poderá medir o grao de cumprimento, ou non, dos 14 puntos que se propoñen mediante un sistema de semáforo. Isto permitiralle tomar consciencia e dar pasos na mellora e compromiso pola sustentabilidade como xeito de facer cultura. 


\section{UNHA CULTURA PARA SOSTER O MUNDO}

Tras a longa noite de pedra da ditadura, no Estado español iníciase todo un deseño institucional en clave de políticas de acceso, de promoción e de protección do patrimonio cultural que desenvolve o concepto do estado como garante do achegamento universal á cultura. É tamén, a partir da década dos 80 , que é cando se consolida a dicotomía estadomercado e a correspondente asociación do público ao estatal e o privado ao mercantil, obviando o comunitario, en tanto as teorías desenvolvementistas impregnaron a visión do que era o atraso e a modernidade. A partir dos anos 90, coa globalización e co impulso das cidades-marca, chega a visión da cultura como motor económico, onde a intervención do estado pasa a estar ao servizo do estímulo das industrias deste sector, o que leva consigo a mercantilización dos recursos culturais.

Converteuse así a cultura nunha mercadoría máis e as políticas do sector céntranse en maior medida na promoción e na distribución e menos na participación e mediación. A aposta pola centralidade das industrias creativas despraza a outros modos de facer como son o asociacionismo, o cooperativismo, a cultura de base ou o fomento de espazos de produción independentes. Desta maneira, insírese como un piar máis das sociedades de consumo, onde a cidadanía se converte nun mero consumidor.

Como consecuencia, contribuíuse, entre outras cuestións, a unha desconexión entre política e cultura que desencadeou un distanciamento entre sector e cidadanía. As liñas de traballo centráronse nesta como obxecto, como produto e non como práctica simbólica ou modo de facer. Con todo, a cultura ten que ver tamén coas maneiras nas que, como cidadanía, nos relacionamos ou facemos xuntos. Xa que logo, concibila como mercadoría supón o risco de que a produción de subxectividade estea suxeita única e exclusivamente aos ditados do mercado, con todo o que iso supón de homoxeneización.

Fronte á visión da cultura como industria creativa ou como turismo, existen outras prácticas culturais que foron relegadas, a ollos da alta cultura, á invisibilidade e á precariedade. O impacto destes procesos comunitarios é quizais menos tanxible a curto prazo, afastados da inmediatez do desenvolvemento económico, mais son as vías cara a unha cultura e unha sociedade máis sustentable económica, social e ambientalmente. 


\section{Cara a unha xestión comunitaria da cultura: sobre a sustentabilidade social}

Tal e como recolle a filósofa Marina Garcés, apostar por unha política cultural implica desapropiar a cultura, arrincala dos lugares propios que a illan, despolitizan e codifican, para implicala na realidade na que está asentada. Inscribila na realidade supón ampliar o concepto, superar esa desafección entre esta e a vida cotiá e acoller unha visión máis antropolóxica que abandone a vinculación da cultura coa espectacularidade. Unha ollada política da cultura permítenos pensármonos en común, cuestionar e problematizar o mundo no que vivimos e construír imaxinarios alternativos. Considerala común implica unha ruptura coa dicotomía estado-mercado. Trátase de ir máis alá das políticas de acceso á cultura para situar as comunidades nunha posición central como axentes activos e cocreadores.

Na investigación realizada por Artibarri e La Hidra Cooperativa en Gestión Comunitaria de la Cultura en Barcelona. Valores, retos y propuestas sinalan que na cultura comunitaria hai que por de relevancia tres valores: a existencia de persoas que teñen consciencia de pertenza a un colectivo, a existencia de economías de reciprocidade para a satisfacción de necesidades comúns e a intencionalidade por unha mellora das condicións de vida. A aposta polo común pasa pola consideración do individuo como ser cooperativo que traza co resto de membros interdependencias e que é quen de dotarse de normas, dunha gobernanza, para garantir a sustentabilidade dun determinado recurso, que ben pode ser o folclore, un entroido tradicional ou a propia lingua.

En Galicia, os montes veciñais en mancomún representan aproximadamente a cuarta parte do territorio galego, máis de 700.000 hectáreas ${ }^{1}$, o que supón que máis de 150.000 persoas coxestionen o seu territorio. Hai toda unha rede de saberes, de mecanismos de intercambio de información, de toma de decisións, de redistribución e retorno á comunidade, que debería ser estudado e acompañado cunha maior profundidade, en tanto que a súa replicabilidade a outros contextos, como son as prácticas culturais, poden supoñer un espazo de oportunidade para ampliar a ollada da cultura comunitaria. A necesidade de que esta exista non impide o fortalecemento do sistema público cultural, senón todo o contrario. A administración ha de soster estruturas públicas que garantan os dereitos culturais e as necesidades materiais que permitan que as súas prácticas sexan sustentables.

\footnotetext{
${ }^{1}$ Información recollida en https://ovmediorural.xunta.gal/gl/consultaspublicas/montes-vecinais-en-man-comun
} 


\section{0 dereito á cultura como base necesaria para a sustentabilidade}

A sustentabilidade é mais que unha ollada ao mundo desde o ambientalismo. Cómpre que comecemos por facérmonos eco daquilo que afirma José Manuel Naredo $(2018,53)$ : “desprazar [...] desde unha idea de natureza allea á especie humana, que se percibe como un 'ambiente' errático e incontrolado, cara a outra que inclúe a especie humana como parte integrante da biosfera”, aínda máis nun territorio como o galego, cunha fonda antropización.

Garantir pois uns dereitos culturais é unha condición necesaria para camiñar cara a unha transición socioecolóxica. Estes teñen tres vertentes: o dereito a ser (a construír a propia identidade a través das referencias simbólicas), o dereito a participar dunha comunidade e o dereito ao gozo e a emoción e a compartir estas coas demais persoas. No que respecta ao dereito a participar na vida cultural, non só implica a accesibilidade ou a posibilidade de seren receptores, senón que debe terse en conta unha lectura máis ampla que implique a posibilidade de seren axentes activos no desenvolvemento e xestión e participes nos propios procesos de decisión.

No dereito á cultura no Estado déronse dúas propostas ás que cómpre prestarlles especial atención. Por un lado o plan "Fem cultura!”, unha iniciativa pioneira para asegurar o acceso, a participación e o dereito a contribuír á vida cultural de Barcelona. Por outro lado, a Lei foral $1 / 2019$, do 15 de xaneiro, de dereitos culturais de Navarra ${ }^{3}$, que normativiza un conxunto de dereitos que lle permiten á cidadanía o acceso e gozo universal dos contidos culturais, así como detalla tamén as obrigas. É a primeira vez na que o ordenamento xurídico español dota con rango de lei os dereitos culturais, o que supón un claro avance na súa defensa como un ben esencial.

O dereito á cultura é garantía de que a cidadanía teña espazos, estruturas e os orzamentos necesarios para artellar propostas, para acoller e resignificar as herdanzas culturais dos territorios ou xerar para proxectos que repensen, cuestionen e a remodelen relatos hexemónicos; por suposto, tamén para o seu desfrute. Cómpre concibila como facilitadora de lugares de encontro e como dispositivo para producir en colectivo. A cultura é máis que unha exhibición, é un xeito de afondar na creatividade e na experimentación, o que permite buscar solucións ou

\footnotetext{
${ }^{2}$ Acceso ao Plan de dereitos culturais de Barcelona: https://www.barcelona.cat/barcelonacultura/ca/suportcultura/fem-cultura

${ }^{3}$ Acceso á Lei foral 1/2019, do 15 de xaneiro, de dereitos culturais de Navarra: http://www.lexnavarra.navarra.es/detalle.asp?r=51081
} 
artellar prototipos. Crear as condicións mínimas para que isto ocorra é un chanzo necesario na procura de alternativas ás crises climática e poscovid nas que se atopa o propio planeta.

\section{Sustentabilidade ambiental}

As lóxicas de crecemento e desenvolvemento sobre as que se sustentaron as sociedades modernas están actualmente en crise. A construción dun modelo económico baixo a desvinculación da natureza, dos corpos e desresponsabilizándose das consecuencias das súas producións tivo como resultado o traspaso dos límites físicos do planeta, o cal derivou nunha crise ecolóxica sen precedentes. Esta aposta por un crecemento permanente tamén tivo as súas consecuencias no modelo cultural occidental, que creceu ás costas das necesidades básicas que sosteñen a vida. A ollada da cultura exclusivamente desde unha perspectiva de mercado expulsa ás marxes a aqueles procesos que non responden aos tempos nin ao concepto de produtividade sobre o que se sostén o sistema capitalista, pero que son fundamentais na construción de tecido social. É nesta vertente da cultura, xeradora de relacións coas outras persoas e de espazos que nos permite pensármonos como sociedade, onde se atopa a súa capacidade para a transformación social.

Desde os ecofeminismos fálase da necesidade dunhas imaxinacións ecoloxistas e feministas ancoradas na materialidade da terra e dos corpos. É por isto que, se entendemos a cultura como parte fundamental nesta transición ecosocial, as políticas culturais deben vincularse directamente co local, co común e coas necesidades básicas das comunidades. Son os procesos participativos nos que, desde a experimentación, a cidadanía problematiza e pensa alternativas, accionando así a imaxinación política que constrúe soños e anticipa futuros.

Cómpre que se incorpore unha maior consciencia ecolóxica, e tamén, tal e como sinala Jaime Vindel (2020: 350) “deben promoverse transformacións culturais que xeren un cortalume na cosmovisión produtivista/mercantilista e políticas públicas que impulsen medidas concretas de cura ecosocial”. Apostar por una cultura en extensivo (Quiroga, 2020) procura fortalecer procesos que emanan desde a propia sociedade, onde a investigación e a experimentación cultural son tamén pedras angulares das políticas públicas. Trátase de minimizar a pegada ecolóxica, as emisións de carbono, e de facilitar estratexias de consumo de produtos de proximidade potenciando a autonomía das comunidades locais. 
As prácticas culturais tamén teñen impacto ecolóxico, polo que cómpre tomar consciencia e ver accións coas que rebaixalo. Isto afectará ás xiras e á produción e exhibición dos espectáculos, mais tamén cómpre atender as externalidades positivas que xera a cultura á hora de cohesionar territorio, de tecer comunidades resilientes ou de repensar imaxinarios sociais. Así, un espello interesante para a cultura pode ser a agroalimentación e a súa aposta por circuítos curtos de comercialización, de mecanismos de distribución alimentaria de quilómetro cero, polo baixo uso de químicos na produción ou polo mantemento de sementes tradicionais como exemplo da rica variedade xenética. A superación do binomio cultura-natureza permitiranos achegarnos a esta última dunha maneira máis harmónica, recuperando así un xeito de relacionarnos coa terra menos destrutivo.

\section{Cara a unha economía compatible coa vida: sustentabilidade económica}

Pensarmos nunha transición cultural implica tamén cuestionarse cal é a organización das condicións materiais de produción necesaria para soster esta transformación cara a modelos alternativos. A transición económica no sector pode influír en mellorar a situación das persoas que proporcionan o seu capital de traballo, na proliferación de proxectos cada vez máis sustentables economicamente no tempo, e tamén, dada a súa capacidade de influencia, pode ser un eixo fundamental nunha transición en todos os ámbitos da vida.

O soño occidental do crecemento sen límites hai tempo que se esgotou a golpe de crise climática, política e económica. A fraxilidade do traballo e do salario incapaz de cubrir as necesidades materiais para o sustento, a ruptura das aspiracións vitais (por pequenas que fosen) e a caída do mito do progreso propiciaron alternativas lonxe da economía do capital cara á procura de procesos máis democráticos, colectivos e participativos na estruturación económica. Este impulso, dentro da economía social e solidaria, é tamén parte da conciencia de adoptar procesos máis sustentables, que sexan compatibles coa vida en todas as fases de produción dun proxecto. Estas organizacións adoitan estar máis vinculadas co territorio, seguir procesos máis democráticos e apostar por experiencias que impulsen a transformación social.

Desde o sector cultural, nos últimos anos, é cada vez maior o número de experiencias que deciden incorporar esta forma de organización. Aínda así, seguen existindo dificultades na sustentabilidade económica. Esta inestabilidade -xunto coa dificultade 
na interacción coas administracións públicas e os problemas xurídiconormativos-, impiden a consolidación do sector e a falta de fiabilidade deste tipo de entidades para parte da poboación.

Dentro do que se coñece como economía social solidaria non hai unha única estrutura que defina este tipo de entidades, mais alá de que compartan que os beneficios empresariais revertan nos propios socios da empresa. Isto leva a que, a pesar da concienciación cada vez maior e da vontade por parte das firmas que engloban este sector, atopen dificultades á hora de construír unha identidade colectiva.

Para alcanzar un maior desenvolvemento, as experiencias internacionais deixan albiscar como o enraizamento local, a participación de colectivos e a interacción destas entidades coas administracións públicas son indispensables. A construción de alianzas é fundamental no fortalecemento do sector. Ademais, é nestes espazos de interacción de diferentes tipos de entidades onde xorden as propostas máis innovadoras.

Por outra parte, na fraxilidade do traballo cultural, na súa temporalidade e na dificultade de sostemento económico é onde se agocha un privilexio de clase que determina que persoas poden facer deste o seu medio de vida. Así, aquelas que proveñen dun contorno familiar acomodado e aquelas que gozan dunha educación privilexiada son as que poden soster a intermitencia laboral do sector e ter os medios e os contactos para poder desenvolver o seu traballo.

Hoxe, máis ca nunca, evidénciase a urxencia dunhas políticas públicas que atendan as necesidades materiais das persoas traballadoras mediante rendas dignas. A falta da sustentabilidade das prácticas culturais vén determinada pola escasa dotación orzamentaria. Rachar con esta tendencia non pode ser unha demanda exclusivamente sectorial, senón que será posible soamente en tanto que a sociedade reclame o valor da cultura e a importancia que ten na súa vida cotiá. O informe Participación cultural en Euskal Herria: modos, causas e impactos analizou a existencia dunha forte correlación entre a participación cultural e unha maior felicidade. Así pois, xerar un relato claro sobre a importancia da cultura na vida é un dos mecanismos máis eficaces para conseguir maiores apoios sociais, o que logo se manifestará en recursos económicos. 


\section{A cultura ante a Axenda 2030}

No marco internacional, a Axenda 2030 é o plan de acción das Nacións Unidas asinado por 193 países no ano 2015. Nela, determínanse as súas actuacións nos vindeiros anos co compromiso de transformar os marcos de vida cara a un desenvolvemento sustentable tanto económico, como social e ambiental. Semella complicado apostar por unha transformación nas políticas públicas e por un desenvolvemento sustentable sen asumir a dimensión cultural que teñen gran parte dos conflitos e retos contemporáneos, tal e como afirma Alfons Martinell ${ }^{4}$.

Porén, non existe ningún obxectivo específico arredor da cultura. Só a meta 4.7 dos ODS 2030 fai referencia á necesidade de por en valor a diversidade cultural e a achega esta fai ao desenvolvemento. A pesar da súa ausencia, a cultura está presente de maneira transversal noutros ámbitos (saúde, xénero, pobreza, etc.). A transversalidade na que esta debe moverse estratexicamente require unha visión sistémica, entenderse desde o pensamento complexo, onde os diferentes ámbitos do desenvolvemento atopan sinerxías e intercambios nos diferentes valores, coñecementos, linguaxes e códigos de cada un deles.

A ausencia dun obxectivo per se arredor da cultura nos ODS 2030 convida irremediablemente a un cambio na concepción, deseño e implementación das políticas arredor dela. Cómpre poñer de relevancia a súa capacidade para a transformación social e a xeración de novos imaxinarios e valores. A cultura debe ter un maior protagonismo na esfera pública, ser parte, tamén, no debate do devir do planeta.

Mentres, o seu campo de actuación a respecto desta Axenda 2030 debe tratar de inserila nos diferentes ODS tecendo pontes, desenvolvendo alianzas e sinalando a capacidade que ten para influír na consecución destes obxectivos. Algúns dos ODS, como o número 11 (cidades e comunidades sostibles) ou o 5 (igualdade de xénero) e o 1 (fin da pobreza) están atravesados por conflitos de dimensión cultural. Para acadalos, é fundamental desenvolver proxectos que impliquen a participación e mobilización da sociedade civil e a construción de alternativas e imaxinarios cara a outros mundos posibles máis habitables.

\footnotetext{
${ }^{4}$ Intervención nas III Xornadas de Sustentabilidade e Institucións Culturais. Instituto Cervantes [12 de marzo 2019].
} 


\section{A cultura como catalizador: a imaxinación ao servizo do cambio}

De acordo coas estimacións da Axencia Internacional da Enerxía e, atendendo á previsible tendencia de ausencia de investimentos, de aquí ao 2025 estímase un descenso na produción do petróleo de ata un 50 \%, tal e como sinalou Antonio Turiel ${ }^{5}$. Ante a previsible limitación da capacidade das enerxías renovables para o abastecemento enerxético consonte ás necesidades actuais, cómpre activar modelos de habitabilidade na terra que non teñan tanta dependencia do uso da enerxía. A ilusión do crecemento económico ilimitado está en dúbida, o que alerta dun colapso do modelo civilizatorio existente, de aí a necesidade dun cambio de xeito de estar no mundo.

A sociedade, e non só o sector cultural, vai ter que asumir renuncias, como pode ser a limitación no consumo ou a hipermobilidade. Ante isto, precísase dun cambio cultural, que en parte xa se está dando, xa que existe unha maior conciencia social sobre a crise climática. De feito, a mocidade está liderando un proceso de cambio que se manifestou en plataformas globais como Friday for the future, mais como se sinala na obra Guía para un descenso enerxético, posiblemente a mudanza ética "sexa a parte máis difícil de todos os cambios aos que nos vai obrigar o fin da era industrial, pois implica unha mudanza moi profunda que deberá ser ao mesmo tempo interior -individual- e social. O noso principal problema non é técnico ou enerxético, senón -no fondo- cultural” (Asociación Véspera de Nada por unha Galiza sen petróleo, 2014: 174). Moitas das mudanzas están, pois, relacionadas coa aposta pola comunidade, a corresponsabilidade, a lentitude, os coidados ou o cooperativo fronte ao competitivo e a un valor que non debe ser medido unicamente desde paradigmas do custe-beneficio a curto prazo.

O antropoceno está producindo unha crise climática sen precedentes e, ante esta emerxencia, a cultura tamén é un espazo excepcional para a experimentación e a imaxinación de alternativas. A tecnofilia ten os seus límites e a cultura, como mecanismo de creación colectiva que é, pode resultar un espazo de posibilidade cun gran potencial, tanto na denuncia como na activación de preguntas e posibles respostas xunto con outros campos do coñecemento. A transdisciplinariedade, tan típica da cultura, pode traspasar a outros espazos, o que contribuirá na procura de solucións.

\footnotetext{
${ }^{5}$ Intervención no Senado no comité Transición Enerxética [12 de abril de 2021]: https://www.senado.es/web/actividadparlamentaria/actualidad/video/index.html?s= $14 \mathrm{~S} 01101802101$
} 


\section{OS 14 PUNTOS DEFINITORIOS DA CULTURA E SUSTENTABILIDADE}

Determínanse aquí os elementos diferenciais que explicitan a relación no que ten que ver co conxunto de normas, principios ou imaxinarios sociais que abandeiren a sustentabilidade como marco ético. Con todo, tamén determinan como sería unha práctica cultural máis sostible, é dicir aquilo que ten que ver coa praxe cultural.

\section{Boa gobernanza e participación cidadá}

As comunidades deben dispor de espazos nos que seren partícipes da toma de decisións e que permitan desenvolver formas de organización máis horizontais e colaborativas baseadas na corresponsabilidade colectiva.

\section{Diversidade e xustiza social}

A inclusión da perspectiva de xénero, da diversidade sexual, de raza ou os diferentes capacitismos pasan non só pola mostra da diversidade, senón tamén pola activación e o cuestionamento dos modelos sociais. Acoller as disidencias e representar outros corpos e outros modelos de vida é un xeito de contribuír a un mundo máis diverso e amplo.

\section{Capacidade crítica e procura de transformación}

A cultura ten a capacidade de cuestionar modelos sociais ou imaxinarios xerando espazos de encontro onde pensar alternativas e de modificación de marcos normativos.

\section{Retorno á comunidade}

Intencionalidade de traballar na mellora das condicións de vida da comunidade na que se insire o proxecto. O retorno á colectividade é unha condición necesaria para non converterse en extractivistas ou depredadores das culturas ou comunidades locais.

\section{Interacción co contexto local}

Raizame e vencello territorial, herdanza cultural, importancia dos saberes locais, cooperación e diálogo co tecido asociativo. Cómpre distinguir a interacción e vinculación territorial co localismo excluínte.

\section{Financiamento diversificado}

Cómpre ter o apoio equilibrado de diversos representantes para non depender dunha única fonte, o que podería lastrar a continuidade da practica cultural. 


\section{Condicións laborais dignas}

A cultura, tal e como sinalan as asociacións de profesionais, sofre unha precarización económica das traballadoras e traballadores, polo que debe coidarse ese aspecto e mellorar as condicións de todos os axentes implicados.

\section{Fomento de redes de colaboración de empresas do terceiro sector}

Cómpre tecer redes con axentes e comunidades non directamente vinculadas coa practicas culturais, así como apoiar as empresas da economía social (cooperativas, fundacións, empresas de inserción laboral, etc.).

\section{Redistribución}

O impacto económico debe de ser expandido polo territorio e non ficar nunha soa entidade. Debe existir a colaboración no reparto económico entre os diferentes axentes que participan na práctica cultural.

\section{Autonomía}

Capacidade de independencia á hora de levar a cabo a xestión do proxecto, así como apostar por acadar maiores cotas de independencia para as comunidades coas que este dialoga. A aposta pasa pola heteronomía, que, en palabras de La Fundició, sería aquela "cultura que recoñeza a vulnerabilidade e interdependencia de todos os individuos entre si e destes cos hábitats nos que se desenvolven" ${ }^{.}$.

\section{Promoción dos recursos locais}

Ten que existir unha colaboración e interacción co contorno, cos e coas artistas da zona, sen caer en localismos autárquicos, así como promover redes cooperativas para compartir recursos.

\section{Coidado do territorio}

Conciencia do impacto ecolóxico do proxecto e respecto e vinculación coa área na que se inscribe, así como a atención e consideración ás súas principais problemáticas ou vulnerabilidades.

\footnotetext{
6 “Por un arte heterónomo para una vida buena”. La Fundició. Dispoñible en: https://culturayciudadania.culturaydeporte.gob.es/dam/jcr:69b77a14-267c-4219-8a7bf561b7766513/lafundicio.pdf
} 
13. Fomento do uso de materiais e enerxías alternativas sostibles

A colaboración con entidades e provedores que teñan parámetros da sustentabilidade ambiental, así como a concienciación para fomentar o uso materiais e enerxías máis sostibles na comunidade.

\section{Baixa pegada ecolóxica}

Redución da dependencia no uso de enerxías fósiles e do uso do automóbil ou da celebración de eventos nocturnos ou en condicións climáticas adversas, xa que isto incremento o gasto de enerxía. 


\section{A SUSTENTABILIDADE NA PRÁCTICA CULTURAL}

A experiencia é unha fonte de coñecemento. As aprendizaxes que traen as prácticas culturais son o recoñecemento a un saber facer, así como a mostra palpable de que é posible concibir ou facer cultura sustentable. A continuación, recóllese unha selección de 10 proxectos que mostran unha diversidade de prácticas no panorama galego que dun xeito extenso responden á relación entre cultura e sustentabilidade.

Para a selección dos proxectos analizáronse as dúas últimas convocatorias de axudas a proxectos culturais das deputacións provinciais, así como as noticias dos dous últimos anos do portal culturagalega.gal e as iniciativas que están cartografadas nos mapas de culturayciudadania, o que permitiu a preselección de 30 propostas.

A escolla deriva do cumprimento da meirande parte dos 14 puntos sinalados anteriormente (participación cidadá, retorno á comunidade, redistribución, promoción dos recursos sociais, diversidade sexual e de xénero, etc.), aínda que tamén na selección hai un nesgo en termos de equilibrio territorial, xeracional, diversidade de temáticas e de modos de facer, especialmente no impulso das redes.

A vontade deste informe non é establecer os requisitos que determinarían un selo de calidade sobre a sustentabilidade, senón facer unha panorámica dos diversos xeitos de trazar un marco de posibilidades para facer unha cultura sostible. De feito, non todas as prácticas poden responder da mesma maneira, hainas máis grandes, outras máis pequenas ou outras cunha menor proxección, por non ter acceso aos centros tradicionais de lexitimidade. A heteroxeneidade é de por si sustentable e a honestidade é o mellor selo que acredita o bo facer, que é de onde xorden os circuítos de garantía por confianza.

No proceso de traballo mantivéronse conversas coas persoas protagonistas que impulsan os proxectos. Delas emerxen unha serie de achegas e puntos críticos derivados da aprendizaxe desde a propia praxe. Abordar a relación da sustentabilidade e a cultura supón que esta última se entenda como un xeito de facer, de estar no mundo, de compromiso coa terra, de pensar na transcendencia, no legado, de mudanza das relacións entre os seres humanos e non humanos, dun novo contrato social coa natureza, así como saber que hai marxe de manobra na correponsabilidade de activar procesos lentos, sostidos e máis orgánicos e menos frenéticos, onde a cultura volva situarse na relevancia que ten, a de facer que a vida mereza ser vivida. 


\section{ARCA DA NOE}

En Vilar de Santos desde o 2014.

Conversa con Noemi Piñeira.

A Arca da Noe é una iniciativa privada de compromiso co rural que se manifesta a través dun espazo cultural e un restaurante. Unha disco-tasca pola que pasaron máis de 500 grupos desde a súa creación no pequeno municipio de Vilar de Santos, habitado por 794 persoas. Conta cun servizo de restauración no que prima o uso de produtos de proximidade e á vez é un lugar de encontro da veciñanza da zona. A aposta por activar este establecemento no rural é un xeito de vida e un acto de militancia contra o abandono e o despoboamento no rural. A misión da taberna é a procura dunha oferta de calidade e accesible en todas as súas dimensións, tanto no menú como na programación cultural. Lonxe de concibirse como un illa, actúa como unha conectora de sinerxías e un pequeno faro que alumea a comarca da Limia e todo o que acontece neste amplo territorio ourensán.

\section{A comunidade no proceso}

A Arca da Noe é un restaurante, unha sala de festas e tamén un centro CCG social. Para Noemi Piñeiro, a participación das comunidades no proxecto cultural "é natural, forma parte da forma de ser da xente, que ten a necesidade de formar parte dun grupo" Así, nos tempos máis complicados da pandemia, a veciñanza que se sente parte, estivo apoiando o proxecto. Ao construír vencellos técense redes de apoio mutuo, en moitos casos non protocolarizadas. É o común o que sustenta a vida, hai unha interdependencia que se vai argallando neses coidados e naqueles pequenos detalles cotiás de corresponsabilidade. A Arca vai alén da idea da persoa consumidora para situarse na idea de veciño ou veciña, o que facilita a construción dun espazo máis hospitalario.

\section{Gobernanza na toma de decisións}

A Arca da Noe é unha iniciativa privada, pois a toma de decisións final depende da propietaria e o custo diso, á vez, recae nela. Mais este feito non limita que se dea un proceso de escoita activa coa veciñanza e as persoas aliadas coas que constrúe un ecosistema que vai alén do propio negocio. A comunidade participa dun xeito informal, porque a única garantía da supervivencia do espazo xorde desas complicidades.

\section{Retorno á comunidade}

Para Noemi Piñeiro, o impulso da Arca da Noe "é unha maneira de estar no mundo. Coido que é fundamental dinamizar culturalmente a comarca, onde a xente poida expresarse e que haxa diversidade 
xeracional”. Nos territorios rurais cada vez fican menos espazos de encontro e a taberna é un deses lugares paradigmáticos, aínda que hai marxe para a oferta doutras actividades e expresións creativas menos habituais no rural. Moitas comunidades séntense orfas deste tipo de espazos.

\section{Coidado do territorio}

O concello de Vilar de Santos acumulou en só 10 anos (de 2010 a 2020) un descenso do $18 \%$ da súa poboación. Actualmente a densidade é de 41,06 hab/km2, mentres que a media galega é de 91,35 hab/km2. Habitar o territorio é xa de por si coidalo e cantos menos habitantes residan no rural, menor capacidade haberá de contestación ante intentos de acaparamento ou desposuimento que poidan sufrir. O compromiso pasa pola capacidade de habitar coa consciencia de ser unha parte dun todo. De aí que se procuren economías onde prime a proximidade, co consumo de alimentos locais e compras en empresas da contorna. Tamén é fundamental traballar con esas alianzas, coas veciñas e veciños, e tecer desde esa base intercambios con outros como un xeito de acadar comunidades emancipadas.

\section{Redes e vínculos con outros}

A Arca da Noe traballa con empresas da zona coas que comparte visións, como é Carabullas, -que fan aproveitamentos do sabugueiro-, compra a carne de boi do Rego do Coedo ou o pan do forno tradicional de Faragullas. Ademais de tecer esas economías en comunidade, constrúe redes persoais, desas que son íntimas e que axudan a non sentirse sos nun mundo cada vez máis individualizado.

\section{A vida no centro das prácticas culturais}

Impulsar un proxecto destas características nun contorno rural é unha aposta, pois hai unha reciprocidade co lugar e coas comunidades que o habitan e técense redes de interacción mutuas. É tamén impulsar unha aposta pola construción de espazos non hipermasculinizados, onde poida darse unha convivencia entre diferentes xeracións e maneiras de ver o mundo, no que haxa respecto ao xénero ou ás disidencias sexuais.

\section{Condicións materiais mínimas}

Ademais do traballo na taberna, Noemi Piñeiro tamén fai substitucións na escola de idiomas, o que lle axuda a obter uns ingresos mínimos. A activista-empresaria sinala que "se só fose pola viabilidade económica estaría pechado. Hai unha militancia, un acreditar nunha maneira de estar no mundo. Mais ao final o esforzo compensa”, sinala. 


\section{Rol das institucións públicas para garantir a resiliencia da cultura}

As institucións deberían impulsar conexións, facilitar colaboracións en rede e non converterse no monopolio da produción cultural local, así como prover dunhas estruturas mínimas para que sexa a cidadanía a que constrúa os seus proxectos culturais. Cómpre unha aposta pola democratización cultural e unha maior colaboración entre as institucións, de cara a fortalecer proxectos que, como a Arca da Noe, cohesionan o territorio.

\section{BRIGADAS DESEUCALIPTIZADORAS}

En varias localizacións ao longo do territorio galego desde 2017. Conversa con Joam Evans.

As Brigadas Deseucaliptizadoras teñen o seu antecedente na creación dunha asociación local en Froxán (Lousame) no ano 2015. Esta asociación local nace ante a progresiva desaparición dun tecido cultural forte (asociacións veciñais, comisión de festas, grupos de música) e a fagocitación das iniciativas culturais por parte do goberno municipal. No 2016, a través da alianza coa comunidade de montes, naceron os voluntariados ambientais arredor dos conceptos da roga (traballo en común) e o albaroque (convivencia con música, cantares ao desafío, etc.). Ante a dificultade burocrática e de protección xurídico-administrativa, froito dos incendios do ano 2017, desde a comunidade montes chegan a un acordo con Verdegaia (asociación ecopacifista galega) para impulsar as Brigadas Deseucaliptizadoras, coa intencionalidade de estender o proxecto a todo o territorio galego. Desde abril de 2018 as persoas brigadistas pasaron de ser unha ducia a máis de 900 persoas e teñen ás súas costas máis de cen intervencións.

Esta iniciativa trata de mobilizar e coordinar a persoas de todo o país nun voluntariado ambiental na procura de erradicar e substituír a eucaliptización e outras especies invasoras por especies autóctonas de maior valor ecosistémico. Desta maneira evítase que volvan ser o espazo perfecto para a proliferación dos lumes e formen unha barreira natural protectora. Alén da tarefa e acción ambiental, arredor das brigadas, froito da convivencia, hai toda unha serie de iniciativas culturais que van desde os itinerarios, as comidas, os espazos de encontros e debate, os coloquios, a música, etc. Estas propostas e toda a experiencia que se xera arredor delas permiten avanzar na superación do binomio cultura e natureza que estruturou o pensamento moderno. 


\section{A comunidade no proceso}

As Brigadas Deseucaliptizadoras son un exercicio de corresponsabilidade cidadá ante unha necesidade común fronte á parálise dos gobernos. Máis alá do traballo en zonas puntuais do territorio, onde o cambio é totalmente real, baixo estas accións subxace unha demanda política e un discurso que pon a atención na eucaliptización dos montes que transcende o propio traballo das brigadas.

\section{Gobernanza na toma de decisións}

A organización interna das brigadas e as súas dinámicas de traballo dependen do territorio no que se realicen. Normalmente, son as asociacións locais ou comunidades de montes veciñais en mancomún da zona, sempre entidades con utilidade social, as que organizan a súa estrutura interna. Desta maneira, existe plena autonomía en cada un dos nós. Esta organización por parte de entidades locais de utilidade social implica que na meirande parte dos casos sexan de carácter asembleario.

\section{Retorno á comunidade}

Alí onde hai vontade e demanda local nacen as brigadas, isto fai que o retorno sexa parte da identidade do proxecto. Coa súa acción, o espazo gaña en multifuncionalidade e a súa chegada para levar a cabo o traballo colectivo permite que naquelas parroquias con menor densidade ou avellentamento da poboación poidan realizarse grandes accións nun tempo menor. É un xeito de acompañar e facer rede ante a inmensidade das dificultades nos montes: "desde zonas que funcionan con xunta reitora téñennos dito que estas accións axudan a que as persoas comuneiras ou da zona vexan maior valor arredor disto”.

\section{Coidado do territorio}

Vandana Shiva alertou dos perigos do monocultivo tanto na mente como nas plantacións de grande extensión. A defensa dun monte autóctono e heteroxéneo é fundamental para a biodiversidade e tamén na loita contra a problemática forestal. As accións realizadas desde as brigadas non levan consigo exclusivamente o coidado do territorio, senón tamén da comunidade e do patrimonio cultural, do que hai gran presenza nos montes veciñais. A través das propostas que levan a cabo, descóbrense espazos non catalogados en zonas das que non se tiña constancia: curros, petróglifos, etc. Estas poden realizarse grazas a seren unha numerosa agrupación de persoas traballando colectivamente arredor do monte.

\section{Redes e vínculos}

A autonomía á hora de crear o proxecto en función da demanda local, o voluntarismo e a chamada á acción colectiva por parte das Brigadas 
Deseucaliptizadoras é un xeito de facer rede e xuntar forzas fronte a unha dificultade común. A unión do traballo, deixando espazo aos momentos de lecer e de encontro, permite fortalecer os vínculos e crear tecido social, así como artellar un espazo de interacción coa cidade, ao atraer numeroso público urbano.

\section{A vida no centro nas prácticas culturais}

Apostar por un bosque autóctono e diverso protexe os montes da proliferación do lume e isto é unha maneira de coidar a comunidade e de poñer a vida no centro. "Evitar que o lume chegue ás casas non é só coidar o territorio, senón tamén protexer a propia vida” afirma Joam Evans, é promover a acción comunitaria e cidadá como intento para evitar o derrotismo e abordar unha problemática común que non é tratada desde as administracións.

\section{Condicións materiais mínimas}

Algunha das críticas que podería recibir o proxecto é con respecto á voluntariedade do traballo. Esta acción nace ante a inactividade das administracións, da falta de axudas e de programas de traballo da Xunta de Galicia, tamén da falta de investigación nas universidades para descubrir métodos menos agresivos para a erradicación de plantas alóctonas. "O problema é que dicir que o traballo voluntario das brigadas substitúe a un asalariado é unha falacia, xa que se asumiría que alguén está disposto a pagalo ou que podería pagalo “ cuestiona Joam.

\section{Rol das institucións públicas para garantir a resiliencia da cultura}

Un dos problemas sobre o papel das administracións públicas na xestión cultural é a cooptación da programación neste ámbito, aínda que as entidades locais non deben ter o monopolio neste eido. "Hai sitios no rural onde non hai vida fóra do que organizan os concellos” e ante isto pregúntase Joam Evans se "é algo ao que non se pretendía chegar ou era a idea que estaba aí desde o principio?”

\section{CANLE RIBEIRA SACRA}

Na Ribeira Sacra desde 2018, e desde 1998 con Televinte.

Conversa con Mercedes Vázquez.

A Canle Ribeira Sacra é a primeira plataforma audiovisual en liña que lles dá cobertura especifica aos 21 concellos de toda a Ribeira Sacra. O xerme desta iniciativa data de 1998 con Televinte, unha experiencia de televisión local que foi comunitaria no seu inicio. No ano 2009 constitúese a asociación Airoá pero, ante a falta de medios, non foi ata o 
ano 2018-2019 cando comezou a poñerse en marcha o proxecto Canle Ribeira Sacra. As súas principais aspiracións e obxectivos son as de documentar e comunicar o patrimonio material e inmaterial da zona, reforzar as conexións no territorio e facilitar a transmisión entre xeracións, cun claro enfoque socioeducativo nos contextos rurais. Desde o principio, existiron tres liñas de traballo: a investigación-acción, a produción documental e proxectos de comunicación educativa.

\section{A comunidade no proceso}

A comunidade é a protagonista do proxecto. "Se non houbese comunidade, nós non existiriamos” afirma Mercedes Vázquez. A vinculación desta iniciativa coa comunidade local vénse fraguando desde hai anos coa existencia de Televinte. A Canle Ribeira Sacra pretende darlle cobertura a todo o que aconteceu e acontece na zona coa veciñanza como protagonista e consumidora dos seus contidos. Unha programación en liña que procura unha relocalización dos temas tratados, para facelos máis achegados ao lugar e ao conxunto da veciñanza.

\section{Gobernanza na toma de decisións}

A constitución como asociación deriva da forma de entender o traballo e do labor social que pretendía desenvolver a canle. A toma de decisións dáse desde o diálogo e a proposta pode partir de calquera persoa que participe na asociación. Agora mesmo, todas as decisións tómanse tendo como base as necesidades máis urxentes, sempre considerando as limitacións loxísticas do equipo, que frea moitas veces a vontade de levar a cabo algunhas propostas. A precariedade eiva un proxecto necesario na xeración de contidos locais na rede.

\section{Retorno á comunidade}

A Canle Ribeira Sacra é un medio dixital que lle dá visibilidade ás propostas e acontecementos que se dan na zona. Isto contribúe a construír identidade local, a dinamizar o lugar, tecer espazos de encontro e redes no territorio. Á vez contribúen a acadar un relato sobre o rural desde o rural, é dicir, a que a narrativa non estea mediada, que sexa a propia comunidade local a que relata a súa vida, o que é emancipador.

\section{Coidado do territorio}

Abrir unha canle dixital territorializada converte unha comunidade en protagonista e serve de interconector entre os diferentes concellos entre eles e co exterior. Á vez, a Canle Ribeira Sacra é un proxecto educativo, que dá visibilidade e pon en valor proxectos sustentables creando contidos audiovisuais de calidade que mostran referentes da zona con 
base ecolóxica como, por exemplo as reportaxes sobre bioconstrución, a colaboración con Anxo Moure (activista ecoloxista) ou as pezas de cine propio para xornadas como Cinema para Coidar a Terra.

\section{Redes e vínculos con outros}

A canle é tamén unha estrutura "para darlle voz ás inquedanzas doutros colectivos” afirma Mercedes Vázquez. Entre as liñas de actuación do proxecto está o desenvolvemento de traballos colaborativos con terceiros ou a organización de obradoiros con entidades públicas ou co terceiro sector. Tamén colaboraron con outras iniciativas como Vida con Arte no Rural, ou a asociación feminista Pola Miúda, entre outras moitas.

\section{A vida no centros das prácticas culturais}

Desde a Canle Ribeira Sacra apostan pola visibilización de proxectos de carácter comunitario fronte a outros máis monumentais ou que acaparan os focos. Esa atención ao miúdo é unha mostra da empatía por vindicar que en cada lugar hai sensibilidades variadas. O seu enfoque pasa pola aposta por un xornalismo lento, que non estea sometido á ditadura da actualidade, o que permite adaptar os tempos a unha maior compatibilidade coa vida.

\section{Condicións materiais mínimas}

O carácter do asociacionismo e o traballo deste tipo de procesos, moitas veces militante, choca coas necesidades de manter unhas condicións materiais mínimas. Hai un proceso continúo de intento de reequilibrio e de facer compatible o traballo desinteresado coa vida. Existen procesos ou actividades que a canle desexaría levar a cabo ou realizalas doutra maneira, mais a falta de recursos impídelles a súa execución.

\section{Rol das institucións públicas para manter a resiliencia da cultura}

“Quen o vai contar de verdade, quen sabe o que está pasando e quen entende isto somos quen estamos aquí” afirma Mercedes Vázquez, por iso cómpre un maior apoio económico e unha aposta decidida por un medio dixital que se coce a lume lento. Crear contidos dixitais de calidade e con enfoque local é unha contribución á presenza doutros relatos nunha rede na que o inglés está xerando os imaxinarios. A ecoloxía é tamén a variedade de linguas, saberes e expresións culturais, mais para que iso estea presente na rede cómpre un maior esforzo social e económico. 


\section{FESTIVAL AGROCUIR DA ULLOA}

Na Ulloa desde o 2015.

Conversa con Gina Gisbert e Adrián Gallero.

O Agrocuir da Ulloa comeza no 2015 tras a inquedanza dun grupo de oito persoas para celebrar e acoller as disidencias sexuais e de xénero no mundo rural. Consideraban que as celebracións do Orgullo eran sobre todo urbanas e que non tiñan presentes reivindicacións como o dereito á terra, a uns servizos dignos no rural ou a necesidade de relacionármonos dun xeito harmónico coa natureza. Coa organización do festival, procuran visibilizar as diversidades das vidas nese contexto a partir dunha rede tan potente como é a romaría, en tanto esta facilita o encontro; ademais, ao facerse diúrno, convértese nun lugar de encontro interxeracional, como afirma Gina Gisbert “a idea é visibilizarse coas veciñas, todas somos comunidade”.

\section{A comunidade no proceso}

A colectividade non é unha masa uniforme, son persoas, que dun xeito máis ou menos informal se xuntan ante un desexo común ou unha ausencia compartida. Entre os veciños e veciñas que habitan a Ulloa, están Braulio Vilariño, Cristina Valera ou Marta Álvarez, -dos cosméticos Muuhlloa-, e máis persoas que teñen, como di Adrián Gallero, “outros xeitos de habitar o lugar desde outra perspectiva”. Isto permitiu que nunha vila coma Monterroso se puidese celebrar o Orgullo LGTB máis coñecido do país. Mais a comunidade non é só a do equipo coordinador, senón que tamén é a da propia vila, que colabora e participa no festival, ou das persoas que o visitan, que seguramente, grazas ao coidado que alí se percibe, deixan de converterse en público e pasan a ter ese papel de comunidade do festival.

\section{Gobernanza na toma de decisións}

A toma de decisións baséase na confianza e delegación. Para Adrián Gallero un principio chave é "cadaquén faga o que poida e no momento que lle sexa posible, respectar iso en todo o momento e non esixir”, ao que Gina Gisbert engade que no colectivo hai moita escoita e que existen unha serie de regras informais que só acontecen cando se coida e se coñece ao outro, o que permite ir coidando o proceso dun xeito orgánico. O conflito -evidentemente- está presente, mais tamén se dispón dunha serie de mecanismos e protocolos informais para acollelo e tratalo.

\section{Retorno á comunidade}

O Agrocuir non é unha marca, nin unha franquía, mais rexistraron o nome, sabendo que podería ser moi tentador que algunha empresa 
quixese aproveitar o seu capital simbólico. O festival é a materialización dun desexo común que, ante a ausencia dun lecer seguro para as persoas disidentes de xénero ou sexo, deciden impulsar un lugar de encontro, que dialoga e tece o achegamento co resto da veciñanza de Monterroso. Conta Adrián Gallero como na última edición do festival a temática foi a comunidade: "ao principio a estratexia bebía das romarías, ir recadando polos bares, explicándolles o proxecto, os cantos de taberna, repartimos bandeiras polos bares, tratando de que cada edición fosen implicándose un pouco mais.

Un dos grandes cumios da última edición foi levalo á vila, rehabilitar o espazo do Caracacho. Trazamos alianzas con diferentes asociacións locais, celebrouse un partido de fútbol feminino e foi un éxito”. Apunta Gina Gisbert que a idea era tan simple como replicar as fórmulas de celebración tradicional, mais dándolle unha volta. "O colectivo de artistas mulleres concibiu a idea de xogar coa idea do santo ou da virxe patroal que vai de casa en casa e crearon un cono-estandarte do festival”. O proceso, sinalan, "foi orgánico, foise dando".

\section{Coidado do territorio}

Non hai mellor maneira de coidar o territorio ca vivilo de xeito activo e respectuoso. Para Gina Gislbert trátase de "habitar o espazo onde vivimos facendo as cousas que nos gustaría que se fixeran e contribuíndo a que sucedan”. O mundo rural sofre dun imaxinario que o vincula co atraso, co hipermasculinizado ou co rancio, e cómpre rachalo, por un lado coa visibilidade doutras realidades que o habitan, mais tamén coa potencia de contribuír desde o rural a facer do mundo un lugar máis amable coa diversidade.

Trátase tamén de aldeanizar a cidade, facela máis sustentable. Ler o que ocorre nos contextos rurais, aprender dos vellos e das vellas, tecer intercambios de saberes entre xeracións e tamén comprender que procesos foron invisibilizados como formas para garantir as resiliencias das comunidades locais son xeitos de coidar o territorio, tal e como era habitual antes. Poñer a atención niso, como fan desde o Agrocuir, é un xeito de camiñar cara á transición ecosocial.

\section{Redes e vínculos con outros}

Esta iniciativa comezou nunha granxa e de aí expandiuse á vila de Monterroso. O obxectivo foi abrirse, saír do armario como comunidade, non ficar no gueto, pensando a diversidade desde a interseccionalidade. Desta maneira, a mostra da diversidade non é só un escaparate da multitude, senón un mecanismo de transformación e de afectación, un posicionamento político ante procesos de acaparamento, de 
desposuimento do común, de perda de autonomía. Tamén é un ámbito de cuestionamento do hexemónico ou desde onde repensar conceptos como modernidade e progreso e, sobre todo, facelo desde o convite a pensalo entre todas as persoas, de aí a potencia da festa.

\section{A vida no centro das prácticas culturais}

Proxectos militantes como o Agrocuir parten dun traballo voluntario que se realiza baixo premisas políticas, de transformación da realidade. Iso non está exento da contradición que supón que non se remuneren horas de traballo e, por suposto, iso non pode esgotar as vidas das persoas que fan o festival. Coidar ese posible cansazo é fundamental.

\section{Condicións materiais mínimas}

As dedicacións ao festival teñen que ser medidas en función das dispoñibilidades, tempos e ritmos persoais, xa que a militancia políticocultural non pode servir de escusa para estender a precariedade. Con todo, hai firmeza no seu compromiso, cunhas condicións laborais dignas co equipo técnico ou os e as artistas que programan. Pouco a pouco, o festival vaise facendo máis grande, co correspondente incremento de recursos, e aí está un dos seus cabalos de batalla: como continuar e á vez coidar.

\section{Rol das institucións públicas para garantir a resiliencia da cultura}

Para Adrián Gallero, o rol das institucións culturais pasaría por concibilas como un ente que dialoga de xeito horizontal con experiencias máis autónomas, promovendo que as comunidades poidan xerar axencia a través dos seus proxectos culturais e non tanto converterse nas produtoras únicas da programación. Como sinala Gina Gisbert o "ideal sería que en cada vila, cada comunidade se apodere na súa festa, que se atravese. Cada sitio terá as súas inquietudes e a función das institucións sería estar á escoita e ter esa vinculación co tecido sen tender a unificar e uniformizar as festas“. E por iso sería importante que, ademais da colaboración económica, haxa un maior impulso que axude a replicar e a diseminar máis agrocuirs ao longo das máis de 30.000 entidades de poboación de Galicia. 


\section{FESTIVAL DE CANS}

En Cans (O Porriño) desde o 2003.

Conversa con Alfonso Pato.

Na aldea de Cans, unha parroquia d'O Porriño, celébrase este ano, 2021, a 18ª edición do Festival de Cans. Desde a súa concepción, este festival de curtametraxes de produción galega xogou con esta brincadeira co Festival de Cannes francés co que coincide temporal e foneticamente. A iniciativa, organizada pola Asociación Cultural Arela, non contaba na súa concepción inicial con maior intencionalidade ca facer un evento cultural lúdico na aldea vinculado á participación social. Con todo, foi profesionalizándose e deseñando unha folla de ruta e unhas liñas estratéxicas que recollen desexos, inquedanzas e aspiracións e converteuse nun dos festivais referenciais de Galicia e do estado. $\mathrm{O}$ cinema é o eixo transversal a través do que trata de ampliar os marcos da participación e de incidencia a través da vinculación a outras disciplinas, como son a música ou a gastronomía.

\section{A comunidade no proceso}

"O tema da sustentabilidade comezou cun discurso demasiado marcado cara ao ambiental e ao económico e non se trata diso. Con dúas palabras que xa se contradín, desenvolvemento sostible. En contraposición a todo, están as teorías do decrecemento” afirma Alfonso Pato, director do festival.

Desde os inicios a comunidade participou na organización. Desta maneira, conseguiron afastarse do festival-franquía, tomando terra e enraizándose na aldea de Cans. A participación da comunidade é un dos sinais de identidade do festival, así como a superación da dicotomía espazos privados versus espazos públicos, xa que a veciñanza cede baixos, galpóns e alboios para convertelos en salas de cinema. Tampouco é un festival colaborativo onde a comunidade substitúe postos de traballo. Todo o contrario, é un proxecto cultural onde a xente da aldea está no centro do proceso, formando parte, por exemplo, do Xurado dos Veciños e Veciñas, composto por cinco persoas de diferentes idades e diferentes zonas do lugar.

\section{Gobernanza na toma de decisións}

Aproximadamente 15 persoas, un terzo delas habitantes de Cans, compoñen o núcleo da organización, que son as encargadas de definir as guías estratéxicas e as liñas de actuación ao longo do ano. Ademais, tamén as veciñas e veciños, así como o persoal traballador/colaborador 
(arredor de 200) fan achegas e unha valoración cos puntos positivos e os puntos febles que tivo a edición, o que axuda a unha mellora constante.

\section{Retorno á comunidade}

Alén do festival de cine, Cans é un espazo de encontro e convivencia interxeracional. Para Alfonso Pato é fundamental garantir a herdanza e o legado, a continuidade do proxecto, que xa fai 18 anos; por iso, as crianzas de máis de 8 anos convértense en excepcionais guías dos camiños pola vila neses días. Moitos deses nenos e nenas, dos cales algúns xa teñen 16 anos, van rotando por diferentes sectores do festival para coñecer o seu funcionamento. Outro grupo, de 19 e 20 xa forma parte do núcleo da organización.

Alfonso Pato concibe a cultura desde un enfoque extensivo. A incidencia vai alén do obxecto cultural, pois é un xeito de compartir aprendizaxes, de educar a mirada de cativas e cativos animando a facer desde a paixón, de tecer cultura entre a comunidade. O festival é, sobre todo, unha exploración conxunta da potencia do audiovisual como modo de comprender e visibilizar e, en definitiva, de transformar o mundo.

\section{Vínculos e redes con outros}

Máis de 50 empresas da zona participan na iniciativa, mais non son unicamente como provedores, senón que son tamén parte do festival. Hai unha redistribución económica e social, xa que entenden que as comunidades só coidan daquilo do que se senten parte, polo que tecer eses vínculos asegura a súa continuidade. Á vez, o festival está tendo cada vez máis repercusión, como por exemplo a presenza na Bienal de Arquitectura de Venecia a través de "Cans: arquitectura de consenso" proxecto desenvolto polo equipo de Creus e Carrasco.

\section{Coidado do territorio}

Este modelo de facer cultura extensiva tamén é unha forma de coidar o territorio, superar esa idea de cultura extractivista que ocupa un espazo, acada o beneficio e non se preocupa do retorno á comunidade. Neste caso, existe un compromiso coa contorna local, pois tamén incorporan métodos e procesos de vida tradicionais da organización na aldea e, ao tempo, contrátanse empresas de ferraxaría, artesanía, panadaría, entre outras, da redonda.

\section{A vida no centro das prácticas culturais}

Cans é un dos festivais de Galicia que máis recursos propios xera en proporción co orzamento. Non se pode renunciar ao mercado, mais isto non impide que continúe mantendo ese afecto e emoción que se perciben en cada edición. Detrás disto, hai unha vontade: a de poñer a 
vida no centro, de enraizamento, de rexuvenecemento ou a de incorporar a perspectiva de xénero (ben a través dun decálogo de visibilización das mulleres no audiovisual, con xurados paritarios, ben por medio da organización de obradoiros vinculados ás novas masculinidades).

\section{Condicións materiais mínimas}

A respecto das condicións materiais e económicas, foise profesionalizando e hoxe dálles traballo a arredor de 200 persoas. Existe un plan económico para mellorar as condicións, tal e como se leva facendo nas últimas edicións, mais, aínda así, non é suficiente para soster a vida de quen alí traballan, polo que cómpre un maior esforzo por parte das administracións no apoio destes festivais.

\section{Rol das institucións públicas para garantir a resiliencia da cultura}

A cultura, como sinala Alfonso Pato, pode buscar paralelismos cos modelos da agricultura, extensiva e intensiva. A intensiva é aquela que en pouco metros incrementa a súa produción, mais para iso precisa do uso de praguicidas e doutros insumos; pola contra, o outro modelo necesita dunha base territorial maior e conta cun proceso de produción orgánico máis lento. Para Alfonso, a cultura extensiva leva tempo, traballo, e paciencia e dá menos beneficios, pero é moito máis sostible, máis respectuosa coa terra e está en relación co concepto de sustentabilidade: "É un bo momento para mudar todo isto. Cómpre cambiar a mirada e apostar pola cultura en extensivo, de procesos máis lentos, que teñan un impacto no territorio e na comunidade na que se inscriben e, sobre todo, estar alerta co greenwashing das grandes corporacións”.

\section{FESTIVAL DE PARDIÑAS (ASOCIACIÓN XERMOLOS)}

En Pardiñas (Guitiriz) desde 1980.

\section{Conversa con Alfonso Blanco.}

Pardiñas é un festival que fuxe da masificación, busca o contacto, a relación e, como sinala Alfonso Blanco, un dos promotores, "hai un compromiso coa harmonía e a beleza. Buscamos esa posibilidade que ofrece a nai terra”. Nas primeiras edicións incluíron orquestras, tal e como pedía a veciñanza, xa que a escoita forma parte dos trazos dun dos senlleiros festivais folk de Galicia. Máis non só é música, desde a primeira edición realizaron exposicións de artesanía, de escultura e doutro tipo de artes. Polo festival achegáronse escritoras e escritores como Xosé Neira Vilas ou Manuel María, entre outros moitos. "Pardiñas 
ten que axudar a medrar o noso pobo en soños, sobre todo, desde a mocidade”, afirma Alfonso, crego que impulsou a festa do patrón de Pardiñas, xunto cunha comunidade que se involucra ano tras ano cedendo leiras para a acampada e acollendo a quen se achega a esta aldea que se converte durante unha fin de semana na capital musical de Galicia.

\section{A comunidade no proceso}

A Feira e Festa da Música e das Artes, tal e como se denomina, é organizada pola Asociación Xermolos, con sede en Guitiriz, que coordina o festival. Tamén colaboran os veciños e veciñas, que se implicaron progresivamente e, coa lentitude da pedagoxía, creouse un espazo dialéctico entre as visións duns e doutros tecendo un festival cun sinal de identidade que era o da comuñón coa natureza, co territorio e coas comunidades que este acolle. Co tempo, outras persoas foron achegándose á aldea, novos moradores que contribúen a activar tamén o lugar e, sobre todo, tal e como sinala Alfonso, hai unha especial vontade de interacción coa mocidade, de conseguir que se sintan parte do festival. Así, o diálogo e a conivencia son os xeitos de facer dun festival que ao longo de 40 anos acolleu unha gran diversidade musical.

\section{Gobernanza na toma de decisións}

A toma de decisións artéllase desde a Asociación Xermolos que, ademais do propio festival, organiza o entroido, obradoiros e conferencias. Coa porosidade da asociación, o relevo xeracional está garantido, as netas e netos están herdando o compromiso das súas avoas e dos seus avós na organización do festival e de toda a armadura simbólica, identitaria e de ecoloxía de saberes que achega o encontro.

\section{Retorno á comunidade}

A xenerosidade da veciñanza, e tamén da natureza, que acollen con agarimo o encontro vese en que asumen o festival como a festa propia, son as festas patronais, é unha herdanza. Está patente o recoñecemento do saber labrego, o festival "nace de abaixo a arriba, non podemos medrar en froito se non temos raíces. Temos que redobrar os esforzos para manter vivas esas emocións. Ás veces esquecemos ese alimentar os sentimentos”.

\section{Coidado do territorio}

Lonxe da idea prístina da natureza, o territorio é un lugar de interacción dos seres humanos e non humanos coa terra e, nesa ecoloxía de saberes, subxace todo un tecido de formas, de estar e ser no mundo. Alfonso Blanco afirma que "buscabamos esa posibilidade que ofrece a nai terra. 
Costounos nas primeiras edicións que a veciñanza acollera outras formas de vida. A nai natureza é un libro aberto que nos permite o respecto á natureza e ás criaturas. Inicialmente custounos incorporar este novo tempo de facer festa durante a Transición, non entendían que a xente moza fose capaz de crear e que tivesen a capacidade de xuntarse, de organizarse”. Nesa concepción da capacidade de autoinstitución da sociedade é onde radica a visión dun proxecto cultural que coida o territorio e tamén os saberes do lugar.

\section{Redes e vínculos con outros}

A iniciativa ten apoios da Comunidade do Monte Veciñal de Santa Mariña de Lagostelle de Guitiriz, que "entende que o Festival de Pardiñas lle axuda ao lugar”, e tamén do concello e da Deputación de Lugo. Á vez traballa de xeito ecosistémico con asociacións e colectivos da Terra Chá, facendo desta comarca un polo descentralizado cultural de relevancia.

\section{A vida no centro das prácticas culturais}

O lema de Pardiñas é "somos unha vila de artistas", pois o traballo desde a cultura popular vindica a capacidade de creación artística da sociedade e non só dunha elite. No baile tradicional hai resistencia e resiliencia, un compromiso de legado e transmisión e tamén de adaptación e mudanza. Un folclore para a vida e non só para o museo. Unha cultura viva que ten a súa eclosión nun festival, aínda que é no cotián onde emerxe na súa amplitude.

\section{Condicións materiais mínimas}

O Festival de Pardiñas non dispón de moito apoio público, é cativo economicamente, polo que chegan a acordos cos e coas artistas. $\mathrm{O}$ acceso ao festival é gratuíto, buscan non ter como barreira de entrada a económica e procuran a corresponsabilidade de quen asiste para apoiar o festival. Ademais, colaboran coa asociación de Gaiteiros Galegos, que escolleron Pardiñas para a primeira edición da elaboración de instrumentos artesanais en todo o Estado. A ausencia dun apoio decidido por parte da Xunta de Galicia supón un atranco á propia sustentabilidade do proxecto. Por outra banda, a independencia na toma de decisións e o posicionamento ético e político do festival non é sempre comprendida.

\section{Rol das institucións públicas para garantir a resiliencia da cultura}

A aposta pola cultura comunitaria é fundamental, especialmente nos contextos rurais, onde o despoboamento e avellentamento poñen en perigo a transmisión de saberes interxeracionais. Cómpre o impulso de políticas activas de apoio a proxectos localizados nel e con impacto 
sociocomunitario. Para Alfonso Blanco hai que "manter viva a nosa cultura porque tamén axuda a ter saúde. A política debe ter en conta que é un sector importante na nosa economía e que desde a liberdade hai que axudar a mantela viva”.

\section{REDE ALDEAR}

En diferentes localización das provincias de Lugo e Ourense desde xuño de 2020.

Conversa con Cristina González.

A Rede Aldear está composta a día de hoxe polos proxectos A Casa do Río, Asociación Xermolos, Cinema Palleiriso, Sacra Experience, Casa Quindos, Fundación Uxío Novoneyra, Casa Vella, Outonia, Arca da Noe, Ruralisto, Eco dos Teixos, Sil Produccións e Casa Boán. A localización dos proxectos nas provincias de Lugo e Ourense é unha decisión estratéxica e política como xeito de vertebrar o territorio, de compartir recursos e de denunciar a excesiva atención ao eixo atlántico. Desta maneira, a pesar de que cada proxecto goza de autonomía na xestión das súas actividades, existen unhas liñas comúns e a vontade de xuntar forzas e recursos. Así, poden ofrecer unha maior accesibilidade e posibilidade de participación daquelas persoas que habitan o rural.

“A volta á aldea como elección de vida” é unha das premisas comúns que comparten as entidades que integran a rede, tal e como di Cristina González, portavoz da Rede Aldear, para esta conversa. O obxectivo xeral da rede é promover a cultura nas aldeas. En paralelo, están outros obxectivos como "acompañar e facilitar o novo asentamento de proxectos culturais, abrir procesos educativos arredor das propostas artísticas no lugar, xerar espazos de creación e investigación culturais, promover e propiciar actividades de desenvolvemento humano, etc.”

\section{A comunidade no proceso}

Cada proxecto é autónomo e a Rede acolle diferente formas de facer en canto á vinculación de cada un deles coas súas comunidades. A pesar de non contar aínda cun amplo percorrido, un dos obxectivos que se contemplan é promover accións de integración coa comunidade local. Como estrutura, abre a posibilidade de crear espazos de encontro, de fomentar o tecido social e formar unha comunidade en si mesma vertebrada polas 15 entidades que a conforman, na procura de abordar os desexos, problemáticas e vivencias comúns. 


\section{Gobernanza nas tomas de decisións}

A Rede Aldear organízase de maneira asemblearia a través de reunións que se realizan de xeito mensual. Alén do traballo colectivo, tamén é un espazo para a socialización e a festa e, ademais, procura ser un lugar de coidado que acolle ritmos compatibles coa vida e formas de traballo propias da tradición das comunidades rurais, como son a roga e o albaroque. A Rede Aldear está aberta á incorporación de novos proxectos que compartan as liñas establecidas, dentro dun equilibrio territorial, localizados na aldea, con traballo durante todo o ano e promovidos por entidades sen ánimo de lucro ou vinculadas á economía social ou solidaria.

\section{Retorno á comunidade}

Unha das liñas de traballo fundamental da Rede Aldear é a vinculación coa comunidade, o territorio e o aumento da participación. A diversidade de entidades que integran a rede implica que actúen con diferentes intensidades, pero existe unha vontade compartida e o desexo conxunto de apostar polo desenvolvemento rural e un facer comunitario. Estes aspectos súmanse á concepción de Aldear como unha aposta por habitar a aldea, tamén para contribuír a xerar tecido vinculado a propostas que permitan ampliar os marcos do dereito á cultura accesible e como participación fóra da acumulación cultural das cidades.

\section{Coidado do territorio}

"A natureza é un espazo moi interesante culturalmente, por exemplo, para o propio crecemento humano, porque todos vimos sandar e as cidades están afastadas dos ciclos naturais e acaban sendo lugares non habitables” afirma Cristina. Ademais, hai unha aposta por impulsar unha programación cultural en espazos naturais, que son escenarios fantásticos para acoller proxectos escénicos ou musicais, pero especialmente para desenvolver proxectos que se vinculen con procesos máis lentos, compatibles coa vida e que incorporen terra.

Á vez, maniféstase a consideración da cultura como interdependente no ecosistema no que se inscribe. Existe unha concienciación ambiental e moitos proxectos teñen unha clara vertente cara a esta vía ou unha vinculación co sector agrícola. Por outra banda, móstrase a coherencia das persoas que integran a rede a respecto do coidado do territorio a través de pequenas accións individuais que, agregadas, mudan o mundo. Un exemplo é compartir automóbil naqueles desprazamentos necesarios para o proxecto, mitigar o uso de praguicidas na produción agraria ou no consumo produtos locais e ecolóxicos, etc. 


\section{Redes e vínculos}

A convivencia de entidades que levan anos asentadas no territorio con proxectos de recente creación permite facer da Rede un espazo de aprendizaxe e de intercambio de recursos. Funcionar como organización ten a potencia de habilitar espazos de encontro que permiten retroalimentar proxectos e xerar alianzas ante unhas liñas estratéxicas comúns. Son formas de crear comunidade para garantir un soporte e unha resiliencia ante a escaseza de recursos.

\section{A vida no centro das prácticas culturais}

A posta da vida no centro dos proxectos culturais pasa por "atender a un pensamento no que poñemos o humano antes que o económico. Ao final, perdémonos na produción, no traballo e esquecemos o máis importante" afirma Cristina; isto implica apostar por un xeito de facer máis lento que respecte os ritmos e os ciclos de vida.

\section{Condicións materiais mínimas}

Actualmente, a Rede Aldear sostense a través dun traballo militante, desde o voluntarismo. Existe unha cota de socias e os custos son asumidos polo conxunto de persoas que a integran. Prevalece a vontade de, a medida que o proxecto vaia adquirindo unha maior experiencia, sostelo a través dunha financiación mixta (mecenado, crowfunding, subvencións...). Isto permite que as propostas gocen de maior independencia e sustentabilidade económica no tempo e tamén de posibilidades de autoxestión.

\section{Rol das institucións públicas para garantir a resiliencia da cultura}

Cómpre que as administracións amplíen os recursos e contribúan ao fortalecemento do tecido cultural vinculándose a unha cultura máis comunitaria, de procesos lentos e participativos. "Facer pedagoxía fronte á cultura do lecer e do espectáculo”. Ao mesmo tempo, é necesario darlle visibilización e recoñecemento aos proxectos xa existentes e ao seu labor e impacto no territorio. Para concluír, Cristina González recolle unhas palabras de Anxo Moure "Pan e Rosas. Pan para que se nos sosteña, pero tamén rosas: significación, valoración, interese. “ 


\section{REDE GALEGA DE SEMENTES}

En toda Galicia, con nós máis ou menos activos en Betanzos, Redondela, Santiago de Compostela, Ortigueira ou Forcarei, entre outros, desde o 2010.

Conversa con Begoña de Bernardo.

A Rede Galega de Sementes é unha plataforma distribuída a través de nós, un colectivo militante que nace co desexo de contribuír ao mantemento da biodiversidade a través da custodia compartida das sementes locais. $\mathrm{O}$ seu coidado faise a través das tradicionais redes entre pares, espalladas por todo o territorio, que garanten a súa libre distribución en feiras mediante mecanismos como o troco. O obxectivo do colectivo é garantir que este patrimonio siga ao servizo dos pobos e non desapareza, é dicir, que continúe sendo un ben común que se transmite, ademais, en obradoiros sobre saúde vexetal ou accións para o incremento das sementes locais.

\section{A comunidade no proceso}

$\mathrm{Na}$ Rede, ademais de seren os membros da comunidade, quen custodia as sementes, tamén son os encargados de preservar e espallar cada unha das variedades tradicionais e organizar encontros. Á vez, noutro círculo, máis difuso, estarían aquelas persoas que participan nas feiras ou nos obradoiros, que tamén son parte dese amplo tecido. Fan tamén especial fincapé na transmisión xeracional, xa que moitas persoas maiores foron esas coidadoras das sementes e, polo tanto, atesouran esa ampla variedade patrimonial que foi intercambiándose ao longo do tempo entre a veciñanza en diferentes localizacións galegas.

\section{Gobernanza na toma de decisións}

A organización confórmase mediante nós locais, xa que é máis sinxelo e ecolóxico que a xente poida acudir a un lugar próximo e, ademais, así pode achegar sementes que teña gardadas na súa casa e que puidesen estar un pouco esquecidas ou a piques de perderse. Cada lugar pode formar un nó e tomar as decisións que considere, soamente hai unha norma: quen queira coller sementes, ten que levar algunha, é dicir, debe haber un troco, aínda que tamén hai un remanente das que sobran e, quen non teña ningunha que levar, pode coller desa cota.

\section{Retorno á comunidade}

Para Begoña de Bernardo o feito de recoller e intercambiar "é un acto de rebeldía contra os procesos de rexistro comercial de sementes. Quen as controla, manda na comida”. Cantas máis persoas custodien e compartan sementes, máis garantía haberá de que sobrevivan. O retorno 
á comunidade asegúrase mentres non se faga un uso privativo-exclusivo delas. É unha contribución para que sigan sendo propiedade común de todos e todas.

\section{Coidado do territorio}

Os procesos de mellora xenética tradicionais danse de xeito orgánico a través dun proceso de relación simbiótica entre a terra, o clima, o ser humano e non humano e a propia semente. Recuperar e recoñecer os seus procesos tradicionais de innovación constante é unha aposta pola superación da dicotomía natureza e cultura e facer intercambios de sementes tamén é cultura. Como afirma Begoña de Bernardo "a feira do troco é desde logo unha manifestación cultural absoluta, é un día de celebración, é unha especie de romaría actualizada”. O compromiso co territorio é inherente á iniciativa.

\section{Redes e vínculos con outros}

O Sindicato Labrego Galego e entidades formativas como o Centro de Formación e Experimentación Agroforestal de Guísamo, que lles facilitou sementes, son algunhas das relacións estables que manteñen con colectivos. Destaca, sobre todo, a proximidade con toda a comunidade relacionada coa agroalimentación, coa que constrúen, en definitiva, vida.

\section{A vida no centro das prácticas culturais}

A ruptura dos círculos de autosuficiencia veu determinada pola convicción de que a especialización funcionaba mellor, e isto vai asociado a unha cultura masculina na que o que prima é a produtividade. Para Begoña de Bernardo "a mecanización vai moi unida ao dominio. Conquistamos a natureza. Desde o punto de vista da mecanización, fíxosenos crer que o noso territorio era defectuoso. Baixo a miña perspectiva, o que hai que pedir é que a tecnoloxía se axeite ao traballo nas nosas condicións. Esa agricultura máis ecolóxica, máis adaptada ao territorio, asóciase en maior medida a ese coidado da vida, un xeito de facer máis ecofeminista que respecta as condicións do propio territorio”.

\section{Condicións materiais mínimas}

A burocratización, a intensificación mercantil e a especialización actual provocaron unha perda de autosuficencia, "traballar para o mercado aniquila a vida. O mercado o único que fai é presionar e seguir presionando a parte máis feble, as produtoras agrarias”, de aí que procesos como a Rede Galega de Sementes teñan un claro enfoque de reversión da tendencia actual á desigualdade na cadea alimentar. 


\section{Rol das institucións públicas para garantir a resiliencia da cultura}

A cultura ten un papel fundamental para repensar os valores e as necesidades humanas. Á vez, é necesario relocalizar a produción e o consumo, cunha aposta clara pola proximidade. Begoña de Bernardo alerta dos perigos da "hiperdixitalización derivada da pandemia", especialmente polos oligopolios empresariais. Eses monstros comerciais traerán novas dependencias inusitadas, o que implicará unha mobilización de recursos e marcos éticos para as que aínda non estamos preparados como sociedade.

\section{REDE DO PATRIMONIO CULTURAL}

En todo o territorio galego desde 2017.

Conversa con Soledad Felloza.

A Rede do Patrimonio Cultural está composta por 103 entidades e acolle aquelas "que teñan como obxectivos a defensa e a posta en valor do legado cultural galego, tanto material coma inmaterial. É un instrumento orientado a aqueles ámbitos territoriais ou sociopolíticos que resultan de difícil acceso para cada unha delas en particular”. Traballan en rede para multiplicar os esforzos e optimizar a incidencia da cidadanía no coidado do patrimonio. As entidades que a compoñen teñen total autonomía para desenvolver os seus obxectivos e conciben a Rede como un espazo compartido na defensa e a corresponsabilidade cidadá na custodia da herdanza cultural.

A ampla participación na Rede dá conta do vizoso que é o movemento cidadán na defensa do patrimonio, mais tamén da inquietude ao redor da súa salvagarda e mantemento. Soledad Felloza, unha das súas activistas, considera que "o territorio fala, e non coidalo é non conversar sobre a memoria do país”. A súa situación é unha mostra da relación co noso pasado e presente e, aínda que a conservación debera mellorarse, o amplo número de entidades, colectivos e persoas que traballan a prol do patrimonio en todo o territorio galego é a proba da intensidade desa relación.

\section{A comunidade no proceso}

O patrimonio é un recurso da comunidade que, por medio de mecanismos de gobernanza, o coida e o salvagarda. A administración a través do principio de titorización, mira polo seu mantemento. Con todo, cómpre que a poboación teña un papel relevante non só na custodia, senón tamén na xestión e toma de decisións ao redor del. Tal e como sinala Soledad "no momento no que a veciñanza se implica no proceso, 
séntese parte de el”, a maior participación, maior compromiso co patrimonio, de aí a importancia de tecer mecanismos de colaboración e de escoita cidadá, que non teñen por que darse só de xeitos formais. As tabernas, as asociacións locais ou as festas son tamén espazos de relación, onde as visións sobre o patrimonio local forman parte das conversas cotiás co que a veciñanza ten un vencello, pois forma parte da súa experiencia vital.

\section{A gobernanza na toma de decisións}

O traballo técese a través de campañas, unha entidade membro propón unha e se se considera axeitada, toda a rede colabora. Non hai unha comisión directiva, senón unha coordinadora, e cada entidade é independente para desenvolver as súas accións. A rede é unha alianza e un espazo de incidencia sociopolítica compartido.

\section{Retorno á comunidade}

A comunidade é participe a través do asociacionismo, un modelo de cultura da proximidade, de vencello co contexto local. Hai entidades de ámbito galego e outras máis situadas en espazos concretos, de aí o afán de situar o patrimonio na súa contorna, xa que constrúe territorio e relato, mais tamén é conflito, e a comunidade aí ten que ter unha voz que sexa escoitada.

\section{Coidado do territorio}

O dereito ao territorio supón desenvolver accións que sexan proveitosas, mais tamén aquilo que non é só produtivo, como é o caso do patrimonio, a simple vista. Así, cómpre compatibilizar usos, xa que o equilibrio entre as diferentes formas de xestión territorial deben garantir o respecto cara a el. Desta maneira, unha cidadanía crítica é aquela esixente co mantemento dos seus costumes, tradicións e legados e o despoboamento é unha das súas meirandes ameazas. Neste sentido, cómpre recoñecer os diferentes axentes que operan na cadea de valor do patrimonio e, entre eles, destacan as asociacións e entidades veciñais. Soledad Felloza recoñece que as políticas públicas sobre o patrimonio deben situarse máis do lado do coidado e da corresponsabilidade que do punitivo e sinala como a educación patrimonial debera ter unha maior presenza no sistema educativo.

\section{Redes e vínculos con outros}

Son parte da organización entidades pequenas e outras con meirande impacto, que é onde está a potencia deste traballo: na posibilidade de sumar folgos e enerxías. A Rede do Patrimonio serve como plataforma pola que canalizar demandas ou como espazo de aprendizaxe 
compartido. Concíbese como un punto de encontro non só cos membros, senón con outros axentes relacionados co patrimonio, desde a academia aos técnicos ou decisores políticos.

\section{A vida no centro das prácticas culturais}

Afirma Soledad Felloza que "non concibo a vida sen ter relación co patrimonio e co territorio no que vivo", o que mostra que este é parte esencial da vida das persoas. É unha pegada material e inmaterial de moita xente que participou e participa na súa construción e mantemento, por iso o patrimonio debe seguir estando vivo e non como un obxecto alleo ao seu contexto.

\section{Condicións materiais mínimas}

O asociacionismo é consciente dos límites do voluntariado e da importancia do traballo e o coñecemento técnico, de feito, moitos dos membros das asociacións son profesionais no campo da restauración ou interpretación do patrimonio. Tamén a participación cidadá, nucleada desde as asociacións, é un elemento central para a súa valorización. Soledad Felloza considera que "cando a veciñanza está implicada na gobernanza, desde o primeiro momento, hai menos conflitos”.

\section{Rol das institucións públicas para garantir a resiliencia da cultura}

Cómpre unha mudanza nas políticas públicas sobre o patrimonio, na gobernanza co recoñecemento do asociacionismo como axente chave, así como o incremento da participación cidadá na súa gobernanza e unha maior comunicación na toma de decisións. A aposta polas políticas de conservación debe ir cara a mantementos periódicos e non so á atención das urxencias. Á vez débese promover a accesibilidade da información e a dispoñibilidade da documentación na rede, xa que canto máis aberto e transparente é o proceso menores son os conflitos.

\section{RURAL MUTANTE}

Na Veiga e en Viana do Bolo desde 2020.

Conversa con Araceli Macías.

Rural Mutante é un espazo onde facer en común como veciñas e veciños. Xorde en tempos de pandemia como grupo informal e coa intención de darlle resposta á falta de actividade do interior de Galicia, mostrando outros xeitos de facer. Nun primeiro momento, a súa intencionalidade era efémera, coa celebración dos exitosos encontros “Mutante's: xornadas de encontro entre proxectos de innovación rural”. Ante a boa resposta a esta a actividade, decidiron continuar creando o 
xermolo dunha estrutura de apoio ás diferentes iniciativas e ideas que vaian xurdindo no oriente ourensán. Esta é unha resposta ante a desilusión, ante a idea paralizante de que no rural non hai futuro.

\section{Comunidade no proceso}

Rural Mutante é unha comunidade de veciñas. A súa mera existencia, ante a falta de iniciativas na zona, é unha forma de implicalas. O seu carácter de grupo informal propicia que a relación coa sociedade se dea de xeito orgánico. Así, a estrutura está aberta para todas aquelas persoas que queiran darlle forma a unha idea e poñela en práctica. Unha das vontades do colectivo no futuro é poder xuntar e articular xente espallada polo territorio e crear pequenos nós mutantes nas comarcas de Valdeorras e Viana.

\section{Gobernanza na toma de decisións}

Desde os inicios, a organización estivo composta por cinco persoas, das cales tres eran as máis activas. A falta de estrutura e o recente nacemento do grupo fai que as decisións lle correspondan fundamentalmente a quen está na coordinación. Isto non limita o seu carácter aberto e a escoita activa de todas as propostas de fóra, mais o límite é que esas propostas non incumpran os principios éticos sobre os que se sustenta a iniciativa.

\section{Retorno á comunidade}

Alén das actividades levadas a cabo, subxace unha proposta política, que o é "porque reivindica que no rural caben múltiples formas de expresión, que collen todas as formas de vida que un queira ter” afirma Araceli Macías. Isto permite afastarse dos estereotipos e mudar o relato sobre o espazo rural mostrándoo como un lugar diverso. Rural Mutante abre un marco de posibilidade no territorio e de mobilización a partir da activación dun espazo onde se xeren encontros entre as veciñas e veciños da zona para imaxinar o mundo que se quere habitar.

\section{Coidado do territorio}

Xa é unha declaración de intencións emprender un proxecto nun contexto rural e procurar non ser asépticos, de aí que entre as súas liñas de traballo estea o compromiso de loita fronte aos parques eólicos. A activación e dinamización da zona abre un marco de posibilidades de como habitar o territorio. Neste sentido, existe un compromiso co futuro e coa superación da parálise da idea de que non hai volta atrás, que non é posible habitar en concellos tan pequenos como A Veiga, que no 2020 só tiña censados a 857 habitantes. Tecer redes e habilitar espazos de 
encontro interxeneracional é unha forma de habitar o lugar e tamén de coidado mutuo.

\section{Rede e vínculos con outros}

Algunhas das persoas que colaboran en Rural Mutante participan a través doutros proxectos, como a cooperativa socioeducativa Outonía, na Rede Aldear, iniciativa da que, por carecer de estrutura xurídica, non forma parte. Con todo, nos seus principios e liñas de traballo están a vontade de tecer redes e traballar de forma ecosistémica. É un proxecto pequeno, mais a forte expectativa que xeraron as xornadas sobre innovación social no rural é boa proba da capacidade que este ten de tecer vínculos con proxectos semellantes, polo que irremediablemente ten que actuar en rede.

\section{A vida no centro dos procesos culturais}

A recollida, resignificación e reivindicación do legado e a vontade de imaxinar novos mundos e un futuro no rural é un compromiso coa vida e coa veciñanza da zona. Fronte á parálise da análise, fixeron unha aposta decidida por coller as rendas e abrir unha fenda, un sendeiro cara a unha transición socioecolóxica na que as aldeas non poden ficar sen xente.

\section{Condicións materiais mínimas}

Rural Mutante é consciente dos límites do traballo voluntario, xa que o colectivo como grupo informal non proporciona sostemento vital para ningunha das súas integrantes. Algunha delas forma parte, ademais, da cooperativa Outonía, que citamos anteriormente, onde tamén tiveron que facerlle fronte á precariedade. Araceli Macías sinala a necesidade da posta en valor dos traballos socioeducativos, porque "as condicións materiais dignas non se van dar en canto non se valore este traballo”.

\section{Rol das institucións para garantir a resiliencia da cultura}

É preciso executar políticas que acompañen os proxectos tanto a través de recursos económicos como de apoio e seguimento, así como apostar por un cambio de paradigma que posicione a cultura como unha necesidade ante a inactividade nos contextos rurais. "Coa covid paralizouse todo por seguridade e realmente non era seguridade, era comodidade por non preparar cousas. Cómpre traer outras expresións culturais, non hai maior esforzo ca reinventarse. Quitáronlle a festa á xente e non pensaron en facer nada alternativo" afirma Araceli Macías. 


\section{RECOMENDACIÓNS PARA UNHAS POLÍTICAS}

PÚBLICAS ACTIVADORAS DO CAMBIO

\section{PRINCIPIO A. A CULTURA CONTRIBÚE Á COHESIÓN TERRITORIAL E DAS COMUNIDADES LOCAIS}

Concibir a cultura como pegamento social e redutor de inequidades

Potenciar a cultura comunitaria e de base

\section{PRINCIPIO B. CÓMPRE REDUCIR A PEGADA ECOLÓXICA NO ÁMBITO CULTURAL}

Apostar por solucións e proxectos que camiñen cara a unha transición socioecolóxica

Minimizar o uso de materiais e a xeración de refugallos, así como baixar a dependencia no uso de enerxías fósiles

\section{PRINCIPIO C. DEBEN GARANTIRSE UNHAS CONDICIÓNS LABORAIS XUSTAS}

Incrementar o orzamento para o fortalecemento dun sector público cultural e o apoio ás fábricas de creación e produción independente

Condicionar e apoiar as políticas de axudas e/ou contratación mediante estándares de sustentabilidade

\section{PRINCIPIO D. ENTENDER A CULTURA COMO PANCA DO CAMBIO}

Estimular a avaliación de impactos a longo prazo e a contribución da cultura á sustentabilidade

Recoñecer a cultura como vector, como amplificador do cambio 
Impulsar mecanismos participativos, de democratización cultural que garantan o dereito á cultura

\section{Potenciar redes cooperativas para acadar un sector cultural maduro e resiliente}

O recoñecemento da cultura como cuarto piar da sustentabilidade debe manifestarse no deseño e na materialización dunhas políticas públicas que contribúan a acadar un sector cultural máis resiliente e afianzar unha cultura ao servizo da transición ecosocial. Propóñense dez recomendacións baseadas en cinco principios que serven como marco desde o que impulsar unhas políticas públicas activadoras do cambio.

\section{A CULTURA CONTRIBÚE Á COHESIÓN TERRITORIAL E DAS COMUNIDADES LOCAIS}

A cultura contribúe a xerar axencia, especialmente cando se deixa de considerar a cidadanía só como obxecto consumidor e pasa a concibirse como suxeito cultural. Á vez, a cultura, como xeito de xerar innovación social e pola súa capacidade de permeabilidade, pode ter especial énfase na cohesión territorial. Cómpre que os esforzos orzamentarios ou de programación non fiquen só nas grandes cidades ou macroeventos e que haxa un maior reequilibrio nas áreas rurais e especialmente nas provincias de Ourense e Lugo.

\section{Recomendación 1.}

Concibir a cultura como pegamento social e redutor de inequidades

A sustentabilidade vai parella á xustiza social, pois a cultura ten incidencia no cuestionamento das relacións de poder, especialmente intensificadas coa hexemonía do dixital e a concentración nunhas poucas mans. $\mathrm{O}$ acceso libre á cultura é un mecanismo de reversión de inequidades e tamén de denuncia de inxustizas. Debe facerse un esforzo no fomento das culturas minorizadas, da promoción das linguas propias e da ecoloxía de saberes. 


\section{Recomendación 2.}

\section{Potenciar a cultura comunitaria e de base}

A cultura de base e comunitaria é diversificada, descentralizada e extensiva nunha ampla base territorial. É a expresión mutante das identidades e o resultado de creacións colectivas. As culturas de base e comunitarias son a manifestación da participación cultural e da transmisión xeracional, un común que non ten dono. Galicia ten riqueza nas festas, nas músicas populares (tanto rurais, como urbanas) que debe ser potenciado.

\section{PRINCIPIO B.}

\section{CÓMPRE REDUCIR A PEGADA ECOLÓXICA NO ÁMBITO CULTURAL}

A xestión cultural debe tomar consciencia da necesidade da redución da pegada ecolóxica das prácticas culturais. Debe facerse un esforzo na limitación no uso de enerxías fósiles, especialmente no derivado do uso do transporte privado, e tecer procesos nos que se incentive o uso compartido ou alternativo ao automóbil. Á vez a cultura debe concibirse como espazo referencial para a experimentación na procura de solucións transdisciplinares para a redución da pegada ecolóxica.

\section{Recomendación 3.}

\section{Apostar por solucións e proxectos que camiñen cara a unha} transición socioecolóxica

Incorporación ou fomento de proxectos, convocatorias ou programacións que reconecten a cultura coa natureza e/ou aborden cuestións relacionadas cos desafíos globais climáticos e o que isto supón de cara a perda de diversidade, quecemento global ou de perda de recursos naturais.

\section{Recomendación 4.}

Minimizar o uso de materiais e xeración de refugallos, así como a redución da dependencia no uso de enerxías fósiles

Debe promoverse unha maior consciencia do uso da enerxía, xa que este é o primeiro paso para reducir a súa dependencia e isto terá implicacións en xiras, reunións ou programacións. Ao mesmo tempo, debe existir un compromiso de cero residuo e continuar afondando e ampliando procesos como os ecovasos nos festivais. 


\section{PRINCIPIO C.}

\section{DEBE REDUCIRSE A PRECARIZACIÓN DO SECTOR CULTURAL}

“A vaquiña polo que vale”. A cultura ten un custo, son moitos os profesionais que traballan no sector e cómpre unha maior valorización social do seu traballo. As súas implicacións van alén do propio obxecto ou artefacto cultural e iso debe ser recompensado economicamente. A cidadanía, as empresas e as administracións públicas deben aumentar o seu apoio económico en tanto que a cultura é un ben esencial para a vida colectiva.

\section{Recomendación 5.}

Incrementar o orzamento no fortalecemento dun sector público cultural e no apoio ás fábricas de creación e produción independente

O empobrecemento do sistema público cultural debe ser solucionado co obxectivo de garantir o dereito á cultura. $\mathrm{O}$ incremento de fondos públicos debe enfocarse mais á produción de creacións/contidos e non só á construción de equipamentos. Á vez, as administracións deben desempeñar un rol de activadores de procesos independentes e colaborar na súa sustentabilidade económica.

\section{Recomendación 6.}

Condicionar e apoiar as políticas de axudas e/ou contratación mediante estándares de sustentabilidade e dignidade laboral

É fundamental o condicionamento das axudas e fondos públicos á recepción dunha memoria ou código de sustentabilidade. Este debe conter o compromiso de medir e mellorar o impacto na sustentabilidade e dignidade laboral a través de mecanismos áxiles e prefixados por parte das administracións públicas.

\section{PRINCIPIO D.}

\section{ENTENDER A CULTURA COMO PANCA DO CAMBIO}

A sociedade debe incorporar con maior énfase a sustentabilidade nas súas vidas culturais e tamén como principio ético. A cultura, en tanto xerador de imaxinarios, ten un papel destacado na súa contribución como modulador da cultura cívica, o que posibilita unha intensificación da necesidade de repensar os xeitos de consumo ou de relación coa natureza ou con outros seres vivos. Á vez, a cultura é un espazo de creatividade inigualable, o que a sitúa na vangarda na procura de solucións ante os retos do futuro. 
Recomendación 7.

Estimular a avaliación de impactos a longo prazo e da contribución da cultura á sustentabilidade

É necesario coñecer datos sobre os impactos da cultura para activar políticas, procesos e adxudicacións orzamentarias que valoricen a contribución sistémica da cultura alén do impacto económico directo. Debe facerse un esforzo en analizar os impactos, non só os inmediatos, senón tamén aqueles que callan co paso do tempo e que polo tanto deixan un impacto cunha maior pegada.

\section{Recomendación 8.}

\section{Recoñecer a cultura como vector, como amplificador do cambio}

Cómpre desenvolver unhas narrativas claras, un relato do papel da cultura e da arte na contribución de melloras económicas e de impacto sociocomunitario e ambiental. Debe facerse un esforzo para conseguir unha comunicación axeitada de logros e melloras tanto a nivel micro como máis agregado. Á vez, debe superarse a visión da cultura só como unha industria e recoñecer o papel significativo que ten para a vida do ser humano.

\section{A CULTURA PRECISA DUN PACTO SOCIAL QUE SITÚE A CIDADANÍA NO CENTRO}

As estratexias políticas de apoio á cultura deben situar a cidadanía no centro e isto pasa por desenvolver mecanismos participativos, polo fortalecemento da produción cultural (e non só a exhibición), así como da libre distribución de coñecemento. Ademais, tamén pasa pola xeración de espazos autónomos de creación.

\section{Recomendación 9.}

Impulsar mecanismos participativos, de democratización cultural que garantan o dereito á cultura

Deben habilitarse mecanismos que rachen coa separación cultural entre sociedade e institucións culturais. Esta fenda debe ser recomposta pola participación de comunidades que ficaron excluídas, polo que cómpre abrir espazos porosos de toma de decisión conxunta nos que a cidadanía poida participar e incidir nas diferentes etapas da xestión cultural. 


\section{Recomendación 10.}

Potenciar redes cooperativas e a cultura de proximidade para acadar un sector cultural maduro e resiliente

Cómpre facer esforzos no apoio ás redes de cooperación temáticas nas que diferentes axentes compartan recursos e sinerxías, algo especialmente necesario en ámbitos como a comunicación ou a procura de financiamento. As estratexias culturais deben facer un maior esforzo no apoio á madurez do ecosistema cultural galego, á vez que tecer mecanismos de colaboración con outros axentes doutros territorios dun xeito máis cooperativo 


\section{AUTOVALIACIÓN}

Achegamos a través deste mecanismo un xeito de medir o grao de sustentabilidade dun proxecto cultural. Propóñense unha serie de preguntas sobre os 14 puntos que determinan a relación entre cultura e sustentabilidade. A cara verde é a de quen está moi contenta co resultado; a amarela a que ten en certa dúbida e a vermella representa un afastamento no grao de sustentabilidade. Esta ferramenta permite tomar consciencia daqueles puntos fortes e febles da práctica en relación coa sustentabilidade. Tamén permite realizar un primeiro paso, co obxectivo de iniciar as accións que melloren as debilidades en termos de sustentabilidade na práctica cultural analizada.

\section{Gobernanza e participación cidadá}

(O teu proxecto ten espazos horizontais para a toma de decisións? Hai mecanismos recoñecidos
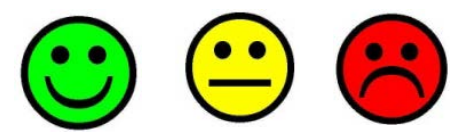
por todas/os para presentar propostas?)

\section{Diversidade e xustiza social}

(O teu proxecto é hospitalario coa diferenza? Hai diversidade sexual, de xénero, orientación
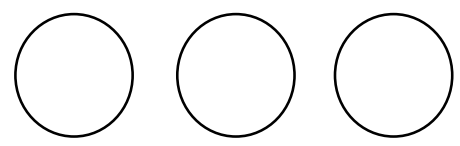
sexual, de raza, de capacitismos?)

\section{Capacidade crítica e procura de transformación}

(O teu proxecto cuestiona o hexemónico ou busca solucións ante malestares contemporáneos? Buscades incidir na realidade?)

\section{Retorno á comunidade}

(Hai vontade de que o proxecto reverta na comunidade, obtén un beneficio á comunidade?
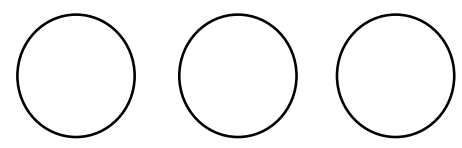

A existencia da práctica cultural mellora o benestar da veciñanza?)
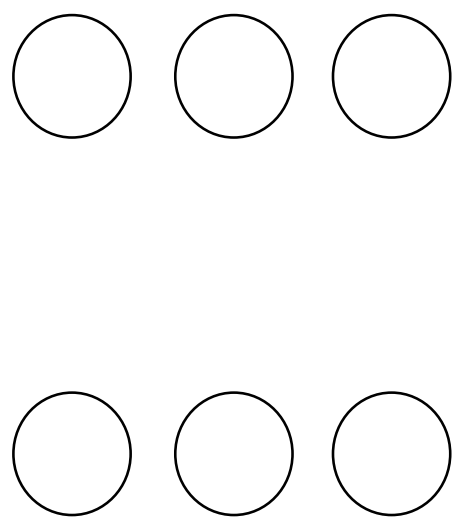


\section{Interacción co contexto local}

(O proxecto dialoga coa escena local, axuda a madurar o ecosistema local? Tece relacións de
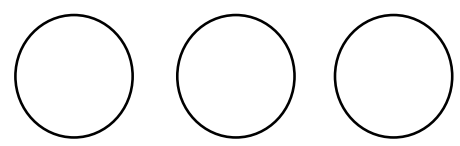
intercambio económico ou de saberes co próximo?)

\section{Financiamento diversificado}

(A práctica cultural dispón de recursos económicos que garantan unhas condicións dignas? E ten fontes de financiamento diversas?)

\section{Condicións laborais dignas}

(O proxecto garante unhas relacións laborais ou mercantís dignas? Hai un esforzo por non esixir
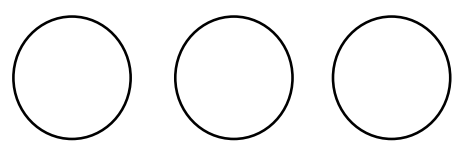
máis por menos? Os recursos económicos son suficientes para cubrir a demanda de traballo?)

\section{Fomento de rede de colaboración de empresas do terceiro sector}

(O proxecto procura traballar maioritariamente
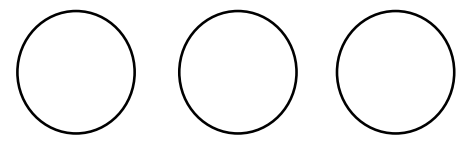
con empresas do terceiro sector? Prima que os provedores proveñan do terceiro sector, é dicir, naqueles proxectos que sen afán de lucro reverten os seus beneficios na actividade social que desenvolven?)

\section{Redistribución}

(O proxecto dialoga co ecosistema local e redistribúe dalgún xeito a riqueza/ingresos económicos ou pola contra só se concentra nas mans duns poucos?)

\section{Autonomía}

(No proxecto hai capacidade de tomar as decisións de forma autónoma, non ten

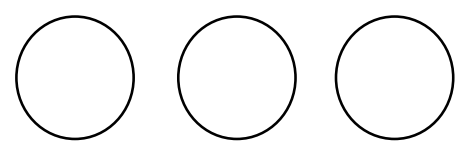
dependencias e, sobre todo, contribúe a que as comunidades coas que dialoga gañen en autonomía?)
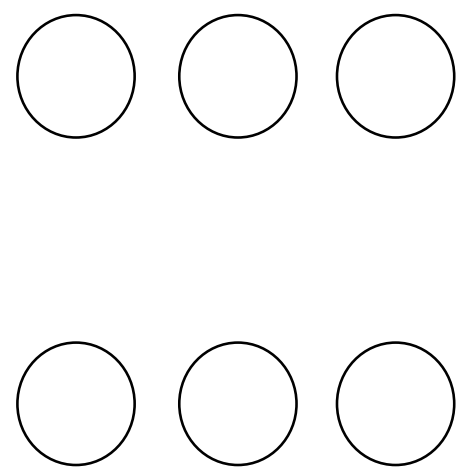


\section{Coidado do territorio}

(Na práctica cultural hai consciencia dos problemas que está a vivir o territorio próximo?
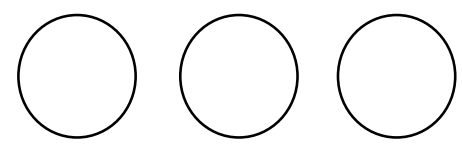

Afróntanse dalgún xeito? Achega a cultura á natureza?)

\section{Uso de materiais e enerxías alternativas sostibles}

(O proxecto cultural achégase ao residuo cero?
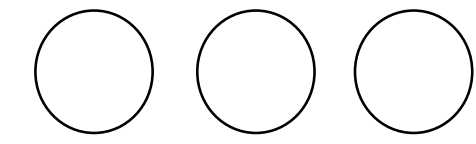

Procúrase o uso de enerxías alternativas ás fósiles? Recíclase material?)

\section{Baixa pegada ecolóxica}

(No proxecto procurades que se comparta o coche, que se consuma pouca luz ou usar a menor cantidade posible de bolsas de plástico?)
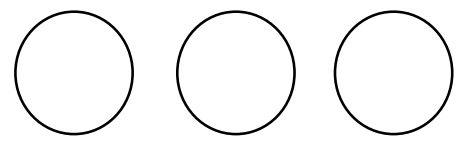

\section{INFORMES}




\section{RECOMENDACIÓNS BIBLIOGRÁFICAS}

AA.VV. (2021): Futuros presentes: conversas sobre cultura e sustentabilidade. Santiago de Compostela: Consello da Cultura Galega. [Dispoñible en http://consellodacultura.gal/evento.php?id=201113].

AAVV (2021). Participación cultural en Euskal Herria: modos, causas e impactos. Observatorio Vasco de Cultura. [Dispoñible en:

https://www.kultura.ejgv.euskadi.eus/contenidos/informacion/keb par te hartze kultura 2020/es def/adjuntos/participacion cultural euskal herria 2020.pdf].

AA. VV. (2021) Brainstorming Report 'Culture and the Sustainable Development Goals: Challenges and Opportunities'. Voices of culture. [Dispoñible en https://voicesofculture.eu/2021/02/26/brainstormingreport-culture-and-the-sustainable-development-goals-challenges-andopportunities/].

Asociación Véspera de Nada por unha Galiza sen petróleo (2014): Guía para o descenso enerxetico. Galicia: Asociación Véspera de Nada por unha Galiza sen petróleo. [Dispoñible en:

http://galiza.pospetroleo.com/acerca-da-guia/].

Fernández Prieto, L. et alii (2021): Cando eramos sostibles. Aprendendo no Barbanza as claves do futuro. Santiago de Compostela: Fundación Ría. [Dispoñible en https://barbanzaecosocial.org/presentacion-primerafase/].

Fernández, R.; Veiras, X. (2019): Mapa Ecosocial de Galicia. Vigo: Catro Ventos Editora.

La Hidra Cooperativa; Artibarri (2018.) Gestión comunitaria de la cultura en Barcelona. Valores, retos y propuesta. Barcelona: Ajuntament de Barcelona: Institut de Cultura de Barcelona. [Dispoñible en: https://transductores.info/properties/gestion-comuntiaria-de-lacultura-2018/].

Quiroga, F. (2019): Hacia una cultura en extensivo. Cultura y Ciudadanía. Ministerio de Cultura y Deporte. [Dispoñible en: https://culturayciudadania.culturaydeporte.gob.es/dam/jcr:f6d136e6e34c-45ce-ab88-ba2311a450a9/fran-quiroga.pdf].

REDS, (2021): Hacia una cultura sostenible. Guía práctica para integrar la Agenda 2030 en el sector cultural. [Dispoñible en https://redssdsn.es/wp-content/uploads/2021/04/Guia-REDS-2021-Web imprimirA4.pdf]. 
Riechmann, J., Matarán Ruiz, A.; Carpintero, O. (2019): Para evitar la barbarie: trayectorias de transición ecosocial y de colapso. Granada: Editorial Universidad de Granada.

Rosanna, L., Louis, T., Thomas I,. Wilson, C. (2020): The Missing Pillar. Culture's Contribution to the UN Sustainable Development Goals. British Council. [Dispoñible en

https://www.britishcouncil.org/sites/default/files/the missing pillar.p df].

Vindel, J. (2020): Estética fósil. Imaginarios de la energía y crisis ecosocial. Barcelona: Arcadia MACBA. 